Published in J. Lewis (Ed), Gender, Social care and Welfare State Restructuring in Europe, Aldershot, Ashgate, 1998, p. 139-174

\title{
Caring for very young children and dependent elderly people in France : towards a commodification of social care?
}

Claude Martin ${ }^{*}$, Antoine Math ${ }^{* *}$, Evelyne Renaudat $^{* *}$

\section{Introduction}

The mid 1980s constituted a turning point for French economic policies, when the public authorities implemented budgetary and monetary policies aimed at curbing inflation and making the French franc stronger. This policy resulted in the growth of public expenditure. The 1990s saw increasing pressure on the public budget due to the goal of matching the Maastricht criteria in the context of a worsening economic situation resulting in dwindling fiscal resources have become insufficient to answer the increasing needs. Growth has been very weak at around $1 \%$ per year on average between 1991 and 1996 (a modest economic recovery of 2,5\% is predicted for 1997 and over $3 \%$ in 1998). This has resulted in a sharp rise in unemployment rates from $8.9 \%$ in 1990 to $12,6 \%$ at mid 1997. Combined with an increase in inequalities, this has led to an extension of poverty and social exclusion. The pressure on public budgets has risen and in spite of frequent new measures for limiting or lowering social protection expenditure, the social Security deficit has remained at over 50 billion francs per year since 1993 (51 billion francs is forecasted for 1997).

All areas of Social protection have to face the scarcity of resources and restructuring. Sectors such as care services are not exceptions. Traditionally, caring for young children and for elderly people represent two very distinct fields of public policy in France. Childhood, especially early childhood, is mostly the concern of family policy which has always been a legitimate field for State intervention. Dependent elderly people, for which concern is more recent, is a matter both for elderly policy and for the field of «action sociale » which, since the decentralisation laws of 1983, is the responsibility of the «départements » (counties). In this contribution, the evolution of care for early childhood and dependent elderly people in public policy issues over the last fifteen or twenty years are discussed successively. In spite of some similarities, both fields cannot be presented in the same way because their respective evolution since the 1980s has been rather different. Early childhood caring policies have been characterised over the period by numerous changes, measures and new laws, mainly aimed at developing and diversifying child-care facilities. It is important to understand these changes, their logic and their impact. There has not, however, been any major decision regarding the question of care for elderly people, at least until 1997, in spite of permanent debates, numerous reports, proposals of laws and, more recently, local experiments. The absence of major change is nonetheless interesting towards an understanding of the policy-making process. Thus, an analysis of this political "non

\footnotetext{
* CRAP - CNRS, Institut d'Etudes Politiques, Université de Rennes I, 104, Bd de la Duchesse Anne, F - 35700 RENNES

** Bureau de la recherche, Caisse Nationale des Allocations Familiales (CNAF), 23, rue Daviel, 75634 Paris Cedex 13.
} 
decision" also appears necessary. While the focus is mainly on the rationale of the evolution in both fields, a basic description of the schemes and data is nevertheless provided for a better comprehension of this evolution in a comparative perspective.

\section{The evolution of public policies regarding early childhood}

Since the beginning of the 1970s, the Family fund («branche famille ») of the Social Security and public authorities have made real efforts in favour of an active policy in the field of early childhood caring, and notably care for the under 3s (Norvez, 1990). Together with the expansion of full-time wage-earning for women, a series of measures was introduced in the 1970s in order to promote the creation and the functioning of different types of collective day care centres: "crèches collectives", "crèches familiales", "mini-crèches", "haltes-garderies" (see glossary in box 1). These measures were a response to women's aspirations for work, but above all to labour market needs, especially in the rapidly expanding tertiary sector.

In 1977, public authorities implemented an official professional status for "assistantes maternelles", the official term for childminders. After a registration/authorisation ("agrément") provided after a home visit by a social worker, a medical examination and a survey of "morality", this status provides "assistantes maternelles agréées" with similar rights and protection afforded to other wage earners.

The « congé parental », an unpaid parental leave, was also created in 1977 (Renaudat, 1993). It can be claimed by either parent (effectively taken quasi-exclusively by women), generally after maternity leave, if the parent has been working for the same employer for at least one year at the time of the birth, but only after agreement with the employer. It may last a maximum of one year. This scheme, part of the « code du travail » (labour legislation) and not social protection, gives legal guarantees: during the leave, employees continue to be entitled to most work-related social benefits and the employer has to make provision for reinstatement at the end of the leave period.

\section{The importance of French "écoles maternelles"}

The aforementioned measures were mostly targeted at children under 3 because care has not been an acute problem for 3-6 year old children for decades. Although compulsory school age is 6 in France, attendance at "écoles maternelles" - state schools - for 3-6 year olds, has long been very common, and was generalised in the 1970s, whatever parents' social status or the mother's position regarding work. Early "socialisation" is considered in France as very profitable for children's well-being and future education. "Ecole maternelle", which is under the auspices of the Education ministry, is enshrined in the French landscape as the first step in education. It is not perceived as child-care. When child-care issues are raised, media, policy makers or experts generally refer little to caring for children over 3, unless for before and after school facilities for children over 3. "Ecole maternelle" is free, following a republican universalistic logic, open all day and is very often completed by optional before and after school child-care facilities ("centre de loisir sans hébergement") inside or near state schools. Because of the existence of «écoles maternelles », child-care needs have always been principally regarded as focusing on the under $3 \mathrm{~s}$. This point must not be underestimated, especially in a comparative perspective. 


\section{Glossary and presentation of main French child-care arrangements}

1. «Crèches ». "Crèche" is a blanket term for the different kinds of collective day centres (described below), while the word "crèche" in English means something rather different. Under the blanket term « crèches » is a diversified delivery system :

«Crèches collectives » are the most common traditional day care centres for children under 3; the facilities are generally high quality (space, equipment) as are the employees or supervisors (number and qualifications). These crèches are generally open from 7 a.m. to 7 p.m. and the average number of places is around 44. They represent around 126,800 places in 1994, including around 7,400 in minicrèches (with a smaller size of around 11 places). There are around 3.6 children per member of staff.

«Crèches parentales » are run by parents' associations. They were created after 1968 but were only officially recognised during the 1980s. The requirements are less stringent than for crèches collectives. They are smaller (between 10 and 15 children). They have the specificity of bringing together parents and employees, of which at least one must have a specific qualification. Parents are present in the crèches between 6 and 8 hours per week. There were around 950 crèches parentales in 1994 (of which 236 in "halte-garderies" type and 477 combining "crèche collective" and "halte-garderie" types) they provided 8,300 places of "crèches collectives" type and 5,600 places of "halte-garderie" type.

« Crèches familiales » is a publicly funded network service that organises and supervises child-care in a registered childminders' home. The contract is between the parents and the local authorities which employ the childminders. Child-care cannot exceed 10 hours per day. There were 1,060 crèches familiales in 1994, composed of 31,700 registered childminders for 65,300 places.

Contrarily to crèches which provide a continual all day long child-care service, «Halte-garderies » welcome children between 0 and 6 years for some hours during the day. They were initially designed for non-working mothers with children under 6 , but are now used largely for part-day care for children whose mothers work part-time, or as a supplementary child-care arrangement. Many "halte-garderies" are linked to a collective crèche ("établissements multi accueil») or to an "école maternelle" (state school) for before-school and after-school child-care (children between 2 and 6).

Crèches are usually open all year round (246 days a year in average in 1990). 62\% of crèches are directly run by communes (local authorities), $25 \%$ by associations (of which all "crèches parentales"), $7 \%$ by "départements" (counties) and $4 \%$ by public sector or State. Crèches are highly subsidised and parents pay an average of $28 \%$ of the cost (in 1990). The payment by parents depends on the resources, on the type of crèches and on the location of the crèche. The average price for parents is estimated at around 71 francs per day in crèches in 1995, 5,7 francs per hour in "Haltes-garderies" and 23 francs per day in "centres de loisirs" (before and after school or holiday facilities). In some areas such as the Paris suburbs, the price for poor families may be very low. Kahn and Kamerman (1994) who studied several child-care places cite the case of a "crèche collective" where the payment may be as low as 4,5 francs per child and per day. Since 1989, tax payer parents can also take advantage of a tax relief : $25 \%$ of net expenditure for collective child-care facilities with a limit of 15,000 francs per year, that is a maximum tax credit of 3,750 francs (per year and per child under seven).

The subsidisation by the "Caisses d'allocations familiales" (CAF), social Security offices, is higher for crèches with a "contrat enfance" (that has replaced the «contrat crèche » in 1988). The "contrat enfance » supports the creation of all types of child-care facilities and covers between 50 and $70 \%$ of supplementary expenditure (60-70\% for communes with fewer than 5000 inhabitants).

140,000 children under 3 attended one of the different crèches in 1990 (source: enquête famille). There are nearly 130,000 places in "crèches collectives" (including "créches parentales" and "multi-accueil" crèches) at end 1993. Representing 5.6 places for 100 children in average, but there very unequal regional disparities (Bussières, 1995). There are also 60,100 places in "haltes-garderie" (source : Bussières, 1995). The number of crèches has increased by around $5 \%$ each year over the last decade.

2 - "Assistantes maternelles" (childminders) 
"Assistantes maternelles", the official designation for the more common "nourrice" (nurse), have a recognised professional status since 1977. Their number varies according to sources (CNAF, INSEE, SESI) between 256,000 and 286,000. Currently, only 142,000 are declared at the special pension fund of independent registered childminders. There are also 32,000 registered childminders employed in the networks of "crèches familiales". Assistantes maternelles are registered ("agréées") for 5 years only after a visit of a social worker at home, a medical examination and a "moral" survey. During this first period of registration, childminders have to follow training for 60 hours (since 1992). Registered childminders are generally older: 60\% are 40 or more, and only 7\% are under 25 (Desplanques, 1993). Legal regulation exists for minimum payments which vary according to the characteristics of the childcare (number of hours, permanent or occasional, continuous or intermittent). The most common situation is when children are cared for all day long and five days a week. The average wage is 2.79 per hour minimum wage per day in 1996 (3.26 in the Paris urban area, 2.7 elsewhere). The average number of children cared for is 1.96 in 1996 (source: CNAF).

Parents using a registered childminder's services may benefit from a special benefit, "aide pour l'emploi d'une assistante maternelle agréée" (AFEAMA). AFEAMA is a non means-tested scheme composed of the payment of social contributions for the employment of a registered childminders (around $40 \%$ of the total costs) and a benefit of 807 francs per month if the child is under 3, and 404 if the child is under 6 (on 1 January 1997).

This benefit can be cumulated with a tax relief that was introduced in 1989 and is equal to $25 \%$ of child-care expenditure in a limit of 15,000 francs per year, that is a maximum tax credit of 3,750 francs (per year and per child under seven).

The use of a registered childminder has sharply increased especially after the increase of the amount of AFEAMA in 1994. Around 380,000 families were recipients at end 1996.

\section{I.1 Increase of collective child-care supply and development of individual and collective regulated formal child-care facilities. (1980-1990)}

The beginning of the 1980s were marked by the first political will for strongly developing child-care facilities. A State secretary for the family, created in 1981, very rapidly set up a group of experts in charge of providing proposals for a policy regarding early childhood. The report Bouyala-Roussille «L'enfant dans la vie » was released in 1982. It underlined three main aspects. Firstly, it noted the child-care policies were too broadly dispersed. Secondly, it insisted on the importance of psychological and physical development («éveil ») and the socialisation of very young children. Thirdly, it reported the strong lack of individual and collective childcare facilities. For $40 \%$ of under 3 year olds, caring arrangements were unknown, supposedly undeclared childminders. Fewer than $10 \%$ attended a day care centre according to this survey ${ }^{1}$.

Beside the lack of child-care supply and the absence of a sufficient diversity, the report also highlighted the strong disparities between the costs of the different childcare facilities.

The report outlined the basis for a policy for early childhood that would consider the child « in the globality of his/her development and of his/her relations with his/her environment, housing, media, transports, possibilities of expression and of cultural acquisition $»$.

It proposed mainly «to organise a system of quality extra-familial caring, education and promotion of health for very young children ». This proposal was an answer to the aspirations of public opinion, which has long been largely in favour of policies promoting collective child-care facilities (see box 2). The future policy should also, according to the report conclusions, «reinforce the whole family and its daily

\footnotetext{
${ }^{1}$ According to "enquête Famille", only $4 \%$ of under 3 year old children were cared for in "crèches" in 1982 (see table 4 supra).
} 
environment in a way to improve its ability to receive, rear and develop the young child ».

\section{I.1.1. A priority given to the increase in places and the quality of collective child- care arrangements (1980 -1984)}

The proposals of this report were taken up by «Caisses d'allocations familiales » (CAF - offices of the family fund of the Social Security) which had decided in 1981 to place child-care as their first priority of their social measures («action sociale »). They implemented in 1983 «contrats crèches» (day care centre contracts) in order to increase the number of places in collective child-care facilities for under 3 year old children (collective crèches, familial crèches and parental crèches). These contracts, drawn up between CAF and communes, are incentives consisting of a supplementary and substantial financial support to communes which committed themselves to the creation of new facilities during the following five years. The number of places in day care centres («crèches ») had steadily increased since the 1960s, but certainly insufficiently in comparison with the increase of women's work and, at the beginning of the 1980s, day care centres were more widespread in rather larger and/or richer communes and in certain regions, especially in the Paris urban area. These new «contrats crèches » were mainly targeted at communes without (enough) day care centres.

At the same time, new laws of decentralisation gave communes sole responsibility for child-care administration. Numerous communes set up an early childhood office («service petite enfance»). It is important to note that, contrarily to «écoles maternelles », there is no legal obligation for a commune or any other public body to create child-care facilities. The incentive provided by the contracts between CAF and communes was certainly insufficient. The goals were not reached: in 1988, only 20,000 new places were created whereas the initial objective was 100,000.

During this period, policies followed two rationales where "l'éveil de l'enfant", the child's development, played a central role:

- a rationale of the development of «proximity» collective child-care facilities, especially by greater public participation and creation of new day care centres.

- a rationale of financial support directly to the families for certain formal regulated child-care facilities. In 1980, the "prestation spéciale assistante maternelle" was created(PSAM). This benefit, reserved for the child-care of 0-3 year old children and to parents already recipient of a family benefit, reimbursed a part of social contributions of a registered childminder's wage.

All of these measures refer strongly to the quality of services, as specified inside the « contrats crèches » or in the requirements for childminders' registration. Moreover, the term « garde » (keep) is gradually replaced by «accueil » (welcome) in child-care vocabulary, because the latter corresponds more to the ideas of «éveil » (psychological and physical development), socialisation and education of young children. 
At the same time, early education ("scolarisation") is encouraged and led to the full generalisation of attendance at "écoles maternelles" of 3 year old children (table 1). It also resulted in the extension of the welcome at schools of one third of two year old children from $10 \%$ at the beginning of the 1970s (table 1$)^{2}$.

Table 1 - Proportion of 2 and 3 year old children attending state schools ("écoles maternelles")

\begin{tabular}{lccccc}
\hline & 1985 & 1990 & 1994 & 1995 & 1996 \\
\hline 2 year old children & 31,9 & 35,2 & 35,4 & 35,7 & 36,1 \\
& & & & & 99,5 \\
3 year old children & 93,3 & 98,0 & 99,5 & 99,7 & 99,9 \\
\hline
\end{tabular}

source : Hée B. (1995)

\section{I.1.2 Diversification and development of collective and individual regulated formal child-care facilities (1985-1989)}

The second part of the 1980s may be characterised both by a continuation of past trends, i.e., increase of child-care supply, and by a will to diversify types of child-care facility in order to answer better families' demands and needs. It is also more difficult to isolate the rationale and to understand the objectives during this period since the policy regarding early childhood becomes increasingly complex. The field has been extended. Before, the measures were mostly targeted at parents with children under 3 and at parents working full-time.

The new measures aim now at covering child-caring for children till 6 years old, and notably by increasing before and after school child-care facilities.

\section{Child-care issues and the ambiguities of the "reconciliation" rhetoric}

In order to facilitate the «conciliation » (reconciliation/compatibility) between family and professional life of wage-earner parents with young children, and notably for parents wishing to suspend or diminish their working activity after the birth of their last child(ren), public authorities modified substantially the «congé parental » in 1984, the unpaid parental leave created in 1977. The maximum duration was extended from one year up to two years, the « congé parental » cannot be refused by employers if the firm is over 100 employees, and the guarantees regarding the job contract are reinforced: the employer is obliged to total reinstatement in the job with a wage that cannot be reduced and at the same conditions - "same work or similar work" - unless restricted by exceptions or situations, such as bankruptcy, redundancies for economic reasons, etc. ${ }^{3}$

Public authorities also created in 1985 «l'allocation parentale d'éducation » (APE), a parental leave benefit, actually a partial compensation for the loss of earnings following a parent's decision to take a period of leave from work and remain at home to care for a new baby. Contrarily to "congé parental", this measure is responsability of the family fund of the social Security and not of labour legislation. This non meanstested and flat rate social benefit is aimed only at families with at least three children

\footnotetext{
${ }^{2}$ but with very large variations between regions. See later.

${ }^{3}$ Needless to say, in the practice, after a parental leave, the parent may not have as an interesting and convenient post in the firm, or she/he may lose possibilities to promotion (Renaudat, 1993, Van de Walle, 1997).
} 
and whose youngest is under 3 years old. In 1986, the condition relative to the interruption of work was softened and the benefit was also extended to a parent that has worked for at least two years during the previous ten years (Fagnani, 1995).

The label «conciliation», reconciliation, of family and professional life which had legitimated most of the early childhood caring policies by enabling women to access the labour market, has become ambiguous since that time. It now also covers the possibility to carry on working thanks to available and appropriate child-care facilities such as the possibility to reduce one's activity or to stop working in order to care for young children.

\section{Diversification of collective child-care facilities}

In the second part of the 1980s, the supply of collective child-care facilities did not concern only full-day permanent caring, but also temporary child-caring when parents work part-time or even when one parent does not work. There is during the second part of the 1980s a certain diversification of the actions which go far beyond the field of child-caring, stricto sensu, since they include parents' expectations in matters of information and/or training, places bringing parent(s) together with their child(ren), school help, etc. The "contrats enfance » (childhood contracts) replaced «contrats crèches » in 1988 whose results were considered insufficient. These new contracts between the CAF and the communes, and sometimes other partners, were more ambitious. The CAF covered a greater part of new expenditure for the development of places of child-care facilities for children under 6 year olds, and not only under 3s. It did not consist of an incentive solely to increase the number of places in day care centres : it was also a support for «multi-accueil» facilities which combined a day care centre with other types such as «haltes-garderie» (non permanent child-care), «ludothèques », etc (for a presentation of this different types, see box 1). It also supported caring facilities for sick child(ren), before and after school child-care facilities, places bringing parents and children together or even « relais assistantes maternelles » which are information and exchange centres for registered childminders and parents. From the mid 1980s, most of the growth in the number of places came from small ("mini-créches") and "multi-accueil" structures rather than more traditional collective facilities ${ }^{4}$.

\section{The first measures in favour of individual child-care.}

The policy of financial support directly to families utilising individual regulated childcare facilities was reinforced. Firstly, the «allocation de garde d'enfant à domicile » (AGED), allowance for child-care in the home, was created in 1987 for parents hiring a domestic employee who cares for under 3 year old children. It consists in the reimbursement of social contributions, at a limit of around $2000 \mathrm{~F}$ per month. Secondly, the status of registered childminders was improved. Thirdly, a tax credit is implemented to cover all formal individual child-care costs (employee in the home, registered childminders, collective child-care facilities).

\footnotetext{
${ }^{4}$ In 1994, the number of places in "mini crèches" (small structures) and "multi-accueil" represents respectively $20 \%$ and $12 \%$ of total places in collective day centres.
} 
Even if the system is more complex, one may consider that it is mostly a continuation of previous trends initiated at the beginning of the $1980 \mathrm{~s}$, i. e., essentially helping families with young children and favouring children's development.

There is however a notable exception, which appears completely contrary to the willingness to improve the quality of caring for young children. AGED is given to families without any requirement on the provision of the service in the parents' home ${ }^{5}$ : there is control neither of the quality of service and the employee's qualification (contrarily to "assistantes maternelles"), nor even for the content of it (the employee may not care for the child at all and fulfil other domestic tasks). The goal of this benefit is to create jobs or to «whiten » otherwise black market jobs. This benefit actually announced the turning point of child-care policies at the beginning of the 1990s.

\section{I.2 Employment policy disrupts child-care policies (1990 -1997)}

In order to enhance the demand for private child-care jobs from families and to curtail the weight of the «black market» in this field, the socialist government implemented a variety of measures at the beginning of the 1990s. They all aimed at facilitating declared employment by simplifying administrative tasks and by decreasing labour costs, notably costs due to social contributions. Any scheme consisting of reimbursing or exonerating from (a part of) social contributions must be considered as important in France since employer's and employee's social contributions constitute a high proportion of the total labour cost, more than $40 \%^{6}$. It is notable that these measures were to be strengthened after the return of a right wing government in 1993.

\section{I.2.1 The promotion of "emplois de proximité" (proximity jobs) (1990 - 1994)}

In 1990, the benefit called «aide pour l'emploi d'une assistante maternelle agréée » (AFEAMA), assistance to families for the employment of a registered child minder, replaced the previous PSAM the results of which were considered unsatisfactory. Despite the increase in the amount in 1987, too few families were recipients of PSAM (45,000 recipients in 1989). The scheme was not well known and non-take-up was very high. It was also reserved for child-care of 0-3 year old children and to parents already recipient of a family benefit. AFEAMA, the new benefit, extended eligibility to families not receiving other family benefits and for child-care of 3-6 year old

\footnotetext{
${ }^{5}$ Encouraging caring for the child(ren) by the mother herself, which is supported by a scheme like APE (parental leave benefit) may also be considered in the same manner. Since very early socialisation in collective child-care or at public schools has been considered very positively in France for children's development and education, it is not incongruous in France to argue that it is better a child to be cared in a day care centre than with an unqualified person, even if the latter is the mother herself. Naturally, there is no consensus on such a statement for under 3 year old children and there are strong ideological oppositions on this point. There is however a very large consensus in the case of 3-6 year old children who very massively attend public schools, even when the mother is economically inactive (see table 1).

${ }^{6}$ This is largely explained by the fact that social protection is largely financed by social contributions rather than other fiscal sources: three-quarter of the financement of social protection in France comes from social contributions (and more than $80 \%$ for social Security). Whereas social contributions represent around $7 \%$ of GDP in the United Kingdom, they amount to $20 \%$ in France.
} 
children. It also covered a larger part of the cost of a registered childminder by reimbursing social contributions within a limit of 5 times the minimum hourly wage per day ${ }^{7}$. It constituted an incentive for not choosing undeclared childminders who were nearly as numerous as registered ones. It could be cumulated with a tax credit equal to $25 \%$ of the actual expenditure in child-care out of home (the tax credit is limited to $3750 \mathrm{~F}$ per year and per child under 7).

\section{2: in favour of individual child-care employment}

In 1992, a simplification of registration procedures was implemented in order to boost the number of registered childminders. Other measures also reinforced registered childminders' professional status, for instance by imposing compulsory training and by raising wages. Supplementary incentives were implemented in 1992 in order to encourage child-caring at registered child-minders' homes : AFEAMA, which had already reimbursed social contributions, was supplemented by a financial benefit in 1992. The payment of social contributions and other formalities were also simplified for AFEAMA recipients.

In the context of the development of regulated child-caring in the home, through the opposition of collective child-caring in establishments, the socialist government promoted the creation of «emplois familiaux » (family employment). It consisted of measures simplifying formalities, facilitating the engagement of an employee and of more generous tax credits. It was targeted at well-off families that were able to afford an employee in the home and pay enough taxes to take advantage of tax credits ${ }^{8}$. The tax credit consisted of half of the expenditure, but with a ceiling of $13000 \mathrm{~F}$ per year. For parents with a child under 3, this tax credit may be entirely cumulated with AGED which already reduced up to two-thirds of the social contributions of a full-time employee (around $2000 \mathrm{~F}$ per month).

The creation of «chèque emploi service », employment service voucher, is also part of the encouragement of family employees in the home. For work of a limited duration ( 8 hours per week), there is no longer any need to establish a labour contract and to provide a pay slip. The employee is paid by means of a "chèque emploi service » which simplifies formalities, notably for the calculation and payment of social contributions.

This period is characterised by a break with the previous policy-making regarding early childhood. Since the beginning of the 1990s, the main goal has been the creation of jobs, as shown by the numerous speeches on the potential of «gisements d'emplois de proximité » (sources of proximity employment). The regulation is radically different : the rational economic logic discards other logics relative to the quality of the service, to the development of child(ren), etc. It also discards more social justice

\footnotetext{
7 Since the minimum hourly wage net of all social contributions is around 30 francs per hour in 1997 and the social contributions are around 22 francs (8 francs of employee's social contributions and 14 francs of employer's ones), Afeama is thus limited to 110 francs per day $(5 * 22)$.

${ }^{8}$ Comparatively to other European countries, income tax is a residual part of total tax in France and is concentrated on well-off households. More than half households do not pay any income tax.
} 
logics such as the diminution of inequalities. The « solvabilisation » (subsidisation) of the potential demand has taken the first, if not only, place. There is, at least, less consideration for the child's needs.

\section{I.2.2 Creating jobs whatever other considerations (1994-1997)}

More recent measures illustrate the deeper submission of early childhood policies to employment policies. This must be placed in a context where all social policies, notably family policy, are now overshadowed by employment policy considerations (Fagnani 1997a, Fagnani, Grignon, 1997). These pre-occupations are behind all recent measures that encourage a massive take-up of private and individual child-care arrangements.

\section{Stronger support for private child-care arrangements...}

The previous impulse initiated or strengthened in 1992 during Beregovoy's socialist government, was consolidated and developed during the right wing Balladur government (1993-1995). The decision to boost the maximum tax credit for an employee in the home from 13,000 francs to 45,000 francs was taken at the end of 1993. In 1994 the AGED was more than doubled to a maximum of around 4,000 Francs per month and was extended to families with a child between 3 and $6^{9}$. Since both advantages may be cumulated, the total subsidy may now cover more than $70 \%$ of a full-time employee (Yakubovich et Grignon, 1996). The effects were rapid and massive : between the end of 1994 and the end of 1996, the number of recipients climbed from 25,000 to 67,000, for around 100,000 under 6 year olds(table 2).

Table 2 - Allocation de garde d'enfant à domicile (AGED)

\begin{tabular}{|c|c|c|c|}
\hline AGED & $\begin{array}{c}\text { Expenditure } \\
\text { (constant million francs 1996) }\end{array}$ & $\begin{array}{c}\text { Recipients * } \\
\text { (thousand on 31st December) }\end{array}$ & \\
\hline & & & .. \\
\hline 1987 & 28 & 2 & right wing Chirac government \\
\hline 1988 & 200 & 9 & socialist Rocard government \\
\hline 1989 & 274 & 11 & \\
\hline 1990 & 292 & 13 & \\
\hline 1991 & 299 & 12 & socialist Cresson government \\
\hline 1992 & 322 & 15 & socialist Beregovoy government \\
\hline 1993 & 462 & 21 & right wing Balladur government \\
\hline 1994 & 539 & 25 & \\
\hline 1995 & 951 & 47 & right wing Juppé government \\
\hline 1996 & 1619 & 67 & \\
\hline
\end{tabular}

* AGED was only extended to overseas departments in 1995

Source : Boissières C. (1997) "Prestations familiales", CNAF..

The incentive for child-minders was also reinforced. The supplementary financial benefit of the AFEAMA scheme was increased by more than $50 \%$ in 1994 (800 F per month and per child under 3, $400 \mathrm{~F}$ if the child is between 3 and 6). Families utilising registered childminders' services receiving AFEAMA increased from 110,000 at the

\footnotetext{
${ }^{9}$ From that time, AGED consists of reimbursing all employer's and employee's social contributions up to a limit based on the monthly minimum wage if the family's younger child is under 3 year old. If the younger child is between 3 and 6 , the reimbursement/refunding is halved. At beginning 1997, the monthly minimum (full time) wage is around 5040 francs net of social contributions. The corresponding social contributions amount to around 3700 francs per month.
} 
end of 1991 to 380,000 at the end of 1996 (table 3). Around 440,000 under 6 year old children were concerned at the end of 1996.

Table 3 - Aide à la famille pour l'emploi d'une assistante maternelle agréée (AFEAMA)

\begin{tabular}{|c|c|c|}
\hline AFEAMA & $\begin{array}{c}\text { Expenditure } \\
\text { (constant million francs 1996) }\end{array}$ & $\begin{array}{c}\text { Recipients } \\
\text { (thousand on } 31^{\text {st }} \text { December) }\end{array}$ \\
\hline 1991 & 586 & 110 \\
1992 & 1935 & 159 \\
1993 & 3321 & 218 \\
1994 & 4320 & 273 \\
1995 & 5729 & 326 \\
1996 & 7032 & 380 \\
\hline
\end{tabular}

Source : Boissières C. (1997) "Prestations familiales", CNAF.

Figure 1

Cost of various childcare for a dual (full-time) earner couple with one child under 3 years old

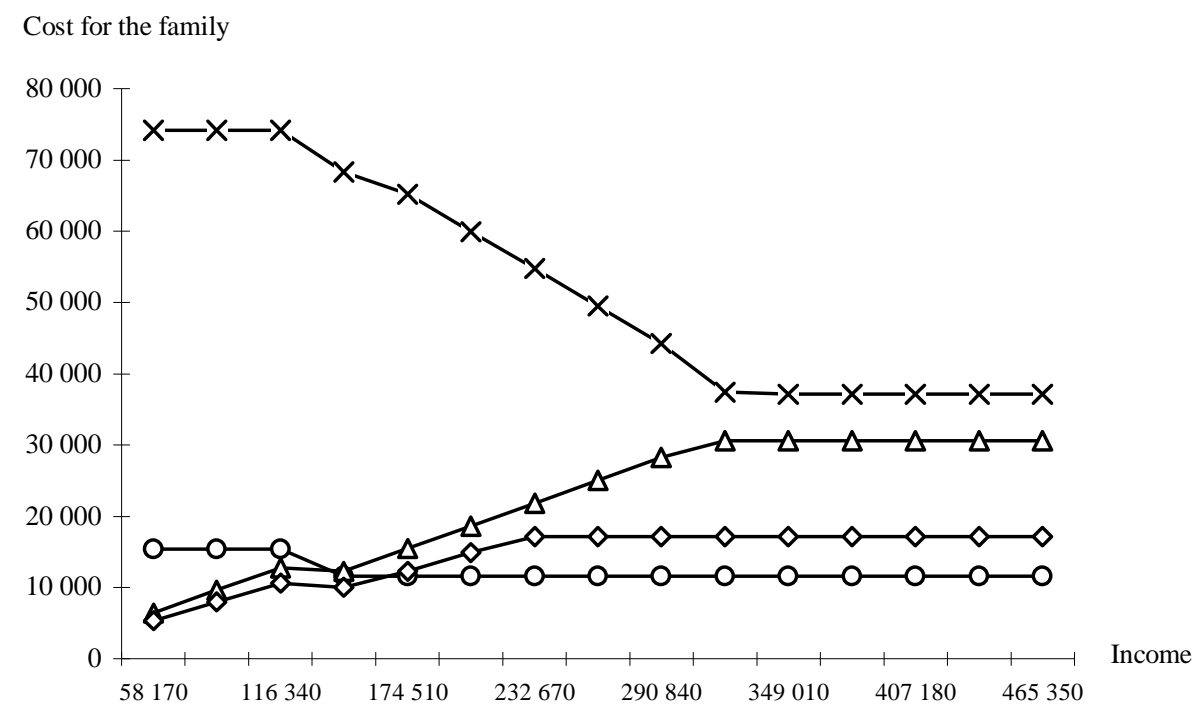

-0 - registered childminders (independent) $-x-$ employee in the home

$\checkmark-$ collective crèche $\quad \sim$ familial crèche

Source: Y. Yakubovich, M. Grignon (1996). See box 2 for the calculations 
Figure 2

Public cost (CAF, State, communes) according to various childcare arrangements for a dual (full-time) earner couple with one child under

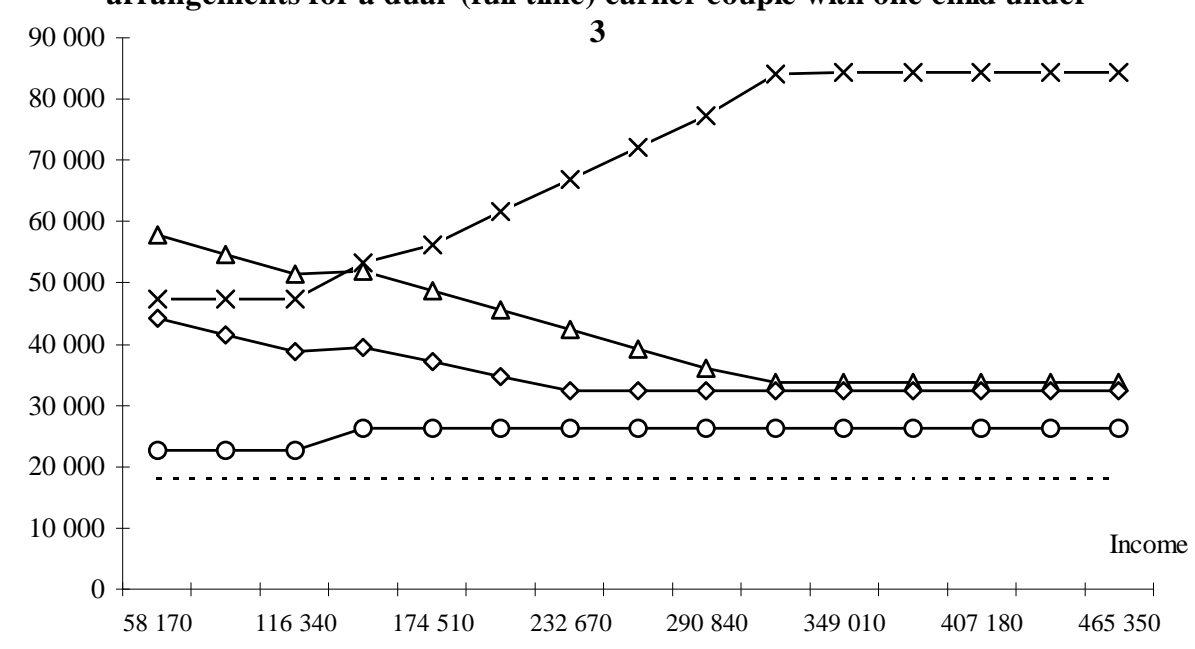

$\longrightarrow$ - registered childminders $-x-$ employee in the home

$\checkmark-$ collective crèche $\quad \checkmark$ familial crèche

- . . . - école maternelle

Source : Y. Yakubovich, M. Grignon (1996). See box 2 for the calculations. 
Assumptions for family model calculations

- « écoles maternelles » (state schools), only for two year old children and older. In this case, the total annual cost is 18,100 francs on average, entirely paid for by the public authorities. No other caring costs are supposed to be chargeable to parents (generally, parents have however to pay a contribution for subsidised lunch).

- "crèches collectives" (collective day care centres) : the child is supposed to be cared for 20 days per month. The total average cost is 292 francs per day. The tariff for parents depends positively on their income, and is calculated according to a "grid" recommended by the CNAF. There is also a tax credit for child-caring outside the home ( $25 \%$ of total expenditure) reserved for tax-payer households and limited to a maximum of 3,750 francs per year (and per child under seven).

- "crèches familiales" (service network of registered childminders paid for by communes): The total average cost is 225 francs per day. The price for parents also depends positively on their income according to a schedule recommended by CNAF. The tax credit for child-caring outside the home applies (3,750 francs per year);

- (independent) registered child-minders : the child-minder is supposed to care for the child 20 days per month for a daily wage equal to 2,25 times the hourly minimum wage ${ }^{10}$. Social contributions are paid through the AFEAMA scheme and there is a supplementary benefit. For tax-payer households, it may be cumulated with the same tax credit as for collective and familial crèches ( 3,750 francs per year).

- employee in the home : she/he is supposed to be employed full-time at the level of the minimum wage. All social contributions are paid through the AGED scheme, that is around 48,000 francs per year for a full-time employee with the minimum wage. This benefit may be cumulated with a tax credit (50\% of child-care expenditure) in a limit of 45,000 francs per year. The tax credit increases with tax liability, that is with income.

\section{... targeted at better-off families}

Formal individual child-care facilities are more advantaged than in the past. The employment policy objectives have resulted in strong anti-redistributive effects in the field of caring for early childhood. New generous measures are targeted at better-off families who employ a carer in the home, and, to a lesser extent, to average and high income families utilising the services of registered child-minders. To illustrate the costs and advantages of different formal regulated child-care facilities for families and public authorities, according to parents' income and to appraise the differentiated public support in the field of child-caring respectively, family models can be used. Calculations are borrowed from work by Yakubovich and Grignon (1996) who studied this question for many types of family models in 1995, differing according to the total number of children, to the total number of under 3 year olds (needing childcare arrangements), to the fact that one parent (i.e., the mother) works part or fulltime, etc. Their conclusions do not differ significantly according to the family models chosen. Here, the family model chosen for an insight is a couple with one child under 3 years old and where both parents work full-time. Other assumptions are given in box 2. It is important to keep in mind that this is only an illustration : the 'choice' between different child-care arrangements does not exist everywhere (especially in rural areas) and does not concern many households. It may be said that the 'choice', and thus the competition between the different child-care arrangements, concerns the rather well-

${ }^{10}$ In 1996, administrative records show that the average dayly wage is 2,79 the hour minimum wage (around 30 francs net of all social contributions), 3,26 in Paris conurbation and 2,7 elsewhere (source : CNAF). 
off families located in the Paris conurbation. The 'choice' is more stringent elsewhere and even purely fictitious in the case of low income families. Moreover, the calculations do not take into account the frequent possibilities to combine several child-care arrangements or to change them as the child grows. Five formal and regulated child-care arrangements are considered : "écoles maternelles", "crèches collectives", "crèches familiales", independent childminders and employees in the home (see box 2). The public support for private child-care arrangements, independent childminders and above all employees in the home, do favour high income families (graphs and 2). "Crèches collectives" are the child-care arrangements which are the most redistributive by taking into account the family's income (graph 1).

\section{Which child-care arrangements for low income families?}

If the formal child-care supply has undoubtedly increased and become more diversified, the greater diversification of facilities has not had an impact on all families needing child-care services. Measures taken in the 1990s concern mainly formal individual child-care facilities. Highly subsidised employees in the home are generally reserved to well-off families (Fagnani et Rassat, 1997a, Fagnani, 1997b). The services of registered child-minders are targeted at a very large part of families with children under 6, but low income households generally cannot afford them. Such families have, however, greater child-care needs than ever due to the evolution of the labour market over the last decade. Increased requirements by employers and flexibility imposed by the labour market to the poorest mean a greater amount of time dedicated to working activities during the day, or even during the week-end and/or at very atypical moments (evening, night...). Low income families can only count, if they exist, on informal child-care arrangements or highly subsidised collective child-care facilities (Desplanques, 1993). More than half of under 3 year old children are cared for by their mother. When mothers work, one fifth of them do not have other childcare arrangements (table 4).

No recent measure has tried to answer this urgent need for economically active or unemployed parents, but also for their children. Equalising chances or preventing exclusion has never been an objective of child-care policies. Only the education sector has shown such a preoccupation by developing the welcome of 2 year old children in priority at the "écoles maternelles" located in poorer areas ("zones d'éducation prioritaire").

\section{Low income mothers encouraged to care at home}

Low income parents, especially mothers, are rather more encouraged than in the past to care for their children themselves. APE, the paid parental leave benefit which was previously aimed at families with at least three children, of which one is under 3 , has been extended to families having a second child in $1995^{11}$. A reduced benefit was also implemented for a parent reducing their activity and working part-time. Only a parent that was economically active before, or that can justify a certain duration of

\footnotetext{
11 At the same time, the possibility of taking a "congé parental" (parental leave) was extended. Till end 1994, parents working for firms with fewer than 100 employees could request the leave but it was subject to the employer's approval. Since January 1995, the approbation is not necessary whatever the size of the firm.
} 
employment during the five or ten previous years is eligible to APE. Currently, more than $95 \%$ of recipients are mothers. APE is designed as an employment policy measure and considered as an incentive for « freeing » jobs (Fagnani, 1995). If it is not strictly a child-care measure, it has obviously an impact on the demand of child-care facilities. Partly because APE is a flat-rate benefit, it is taken up by women on a relatively low income, most often unemployed or with precarious and dissatisfying jobs, who make a trade-off between this benefit and a low wage or unemployment benefit (Afsa, 1996, Fagnani, 1996). Mothers living in rural areas where collective child-care facilities are absent, are also more likely to take up the benefit (Afsa, 1996). In a period of great pressures on the labour market, the extension of APE had an unexpected "success". The number of recipients increased from 174,000 at the end of 1994 up to 447,000 at the end of 1996 (table 5). The current impact of APE in terms of employment policy is however doubtful because a break of several years may hinder recipients from being reintegrated into the labour market when the younger child is three and may result in worsening the unemployment trap. Since most recipients are female, its gendered impact is thus real and there is a likelihood that it will reinforce gender inequality and assigned roles within the households and on the labour market (Fagnani, 1995, 1996).

Table 4 - Repartition of 0-3 year old children according to the the child-care arrangements

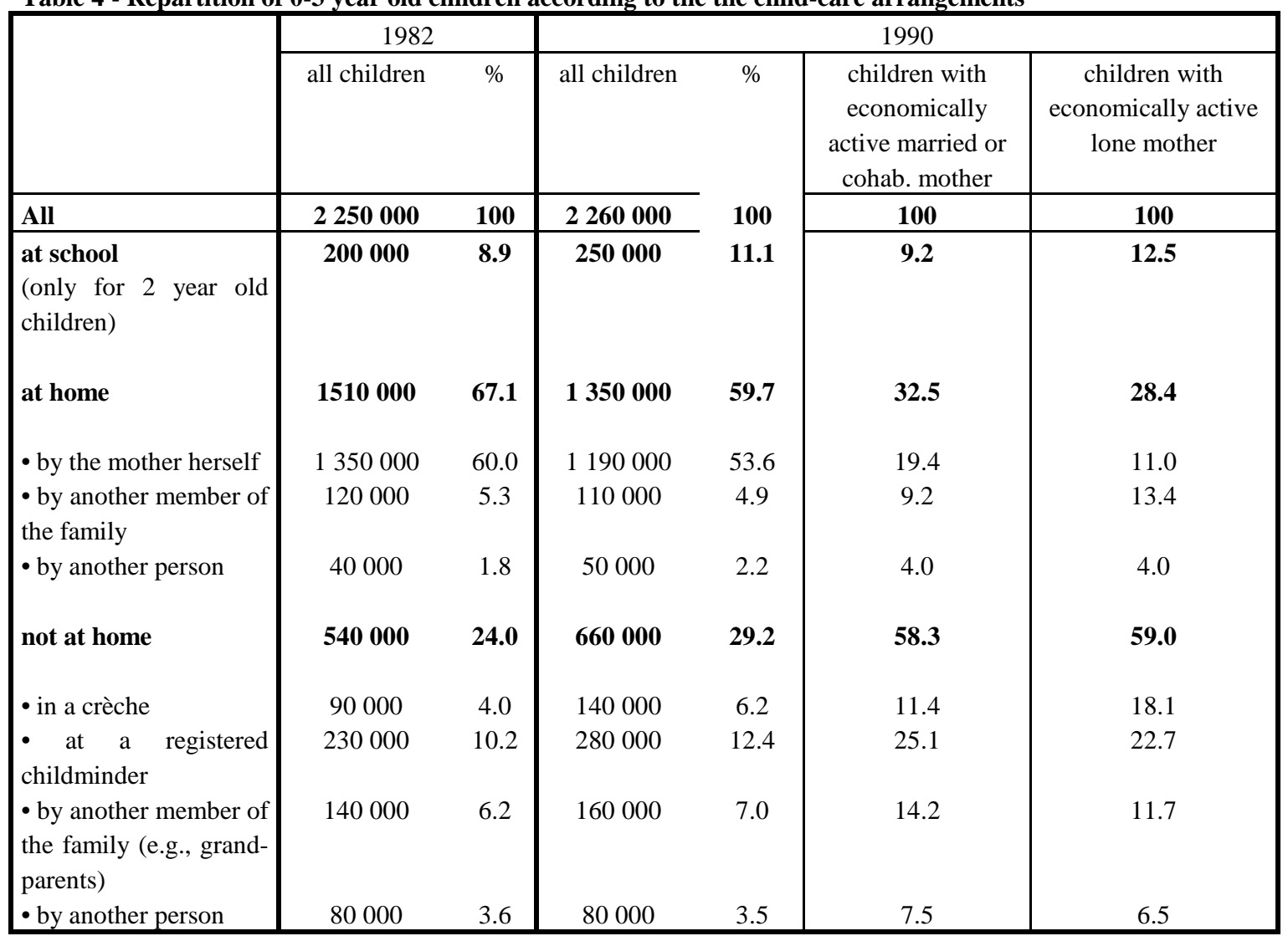

Sources : Desplanques G. (1993) and INSEE (1994), from "enquête famille" (1982 and 1990). 
Table 5 - Allocation parentale d'éducation (APE)*

\begin{tabular}{|c|c|c|}
\hline APE & $\begin{array}{c}\text { Expenditure } \\
\text { (constant million francs 1996) }\end{array}$ & $\begin{array}{c}\text { Recipients } \\
\text { (thousand on 31st December) }\end{array}$ \\
\hline 1985 & 11 & 3 \\
1986 & 358 & 27 \\
1987 & 3845 & 162 \\
1988 & 6802 & 187 \\
1989 & 6911 & 187 \\
1990 & 6794 & 181 \\
1991 & 6542 & 174 \\
1992 & 6172 & 164 \\
1993 & 5895 & 154 \\
1994 & 5969 & 175 \\
1995 & 8331 & 303 \\
1996 & 12567 & 447 \\
\hline
\end{tabular}

* Metropolitan France only.

Source : Boissières C. (1997) "Prestations familiales", CNAF.

\section{Deep redistribution of the generous public package...}

Contrarily to other European countries, the French public authorities have not cut public child-care expenditure, which has not entirely ceased growing and it remains relatively high (table 6). The recent changes had however an important impact in the spread of public expenditure on child-care, largely in favour of individual child-care facilities. Decisions taken over the last decade, dominated by employment policy considerations, have neglected low income families who need available and affordable child-care arrangements even more urgently than other families. In France, this trend continues nevertheless in accordance with all other policies which no longer place the reduction of inequalities as a policy objective (Math and Renaudat, 1997).

Table 6 - Estimation of public expenditure for formal child-care arrangements in 1996 (billions of francs) *

\begin{tabular}{|c|c|c|c|c|c|c|}
\hline & $\begin{array}{c}\text { CAF } \\
\text { (Social } \\
\text { security } \\
\text { Family fund) } \\
\end{array}$ & State & $\begin{array}{l}\text { Communes } \\
\text { or other local } \\
\text { governments. }\end{array}$ & Total & under 3 & $\begin{array}{l}3-6 \\
\text { years }\end{array}$ \\
\hline $\begin{array}{l}\text { Registered childminders } \\
\text { (independent) }\end{array}$ & 7 & \multirow{2}{*}{$\begin{array}{c}(0,5) \\
\uparrow \\
1,0 \\
\downarrow \\
(0,5) \\
\end{array}$} & l & 7,5 & 5,7 & 1,8 \\
\hline Crèches (all types) & 3,6 & & 7,5 & 11,6 & 11,6 & 0 \\
\hline Employee in the home & 1,6 & 1,2 & 1 & 2,8 & 2 & 0,8 \\
\hline "Ecole maternelle" (state school) & l & 28 & 19 & 47 & 4,7 & 42,3 \\
\hline Total & 12,2 & 30,2 & 26,5 & 68,9 & 24 & 44,9 \\
\hline
\end{tabular}

* authors' estimations or calculations from various national sources (CNAF, documents dits "bleus" du projet de loi de finances 1997, Ministère de l'Education Nationale).

Nota : There is a very controversial and ideological issue to consider maternity and parental leave benefit as « child-care » facilities. We have chosen not to include such elements in child-care public expenditure, unless any other benefit towards families with child(ren) under 3 (or 6) years old is considered as child-care public expenditure. Such a position would imply including child benefits, other means-tested or non means-tested family benefits, or even the payment of social contributions to pension funds by the social security family fund for parents who care for their own children. These benefits as well as parental leave benefits have primarily other objectives than child-care even if they may have a real impact on the choice of child-care arrangements. 
The risk of distortions in the child-care sector has often been highlighted (Fenet et Enjolras, 1992). By strongly promoting regulated child-care in the «domicile» (in parents' homes or in childminders' homes), the recent measures have increased the competition in demand, by those families whose needs fall between those arrangements and collective child-care facilities, and, at least in certain areas, have curbed or stopped the development of collective facilities that are supposedly encouraged by other public measures such as "contrats enfance". Currently, the tariffs in "crèches collectives" depend highly on the family's income and the establishments have to compensate the very low contribution by poorer families with those from their better-off clients. In some urban areas, other child-care arrangements, especially employees in the home, are increasingly becoming the preference, especially because they are more convenient for active, dual-earner couples with very stringent professional constraints (Fagnani, 1997b). This recent evolution may rapidly lead to financial difficulties for collective child-care facilities. The promotion of private child-care arrangements has undoubtedly destabilised previous efforts in the development of collective child-care facilities in some areas. Globally, the total supply of places in collective facilities has nevertheless continued to rise for several reasons : these facilities have a very positive image, notably for their recognised beneficial role in the child's development and their low cost for families, as confirmed by regular surveys (Credoc, 1997) ; for middle class families, collective facilities are also perceived as a necessary preparation for school (which receive more than $99 \%$ of 3 and more year old children, see infra table 1) ; the extent of real uncovered needs (table 4) continues to generate a strong demand for this type of facility in many places ; and the incentive from the CAF, with "contrats enfance", plays an important role in certain areas.

\section{The spatial dimension of child-care facilities}

In a sector where the proximity of the child-care arrangement is determining, the impact of recent measures should be, however, very different according to the location, especially between urban and rural areas. The regional and spatial differences in the supply of child-care facilities have currently been very high in France (box 3). National average figures, such as those relative to the proportion of under 3 year old children cared for - at "crèches", at independent childminders, by an employee in the home or, for 2 year olds, attending "écoles maternelles" - must be taken with caution since they correspond to very wide disparities ${ }^{12}$. The development of individual child-care arrangements, notably by childminders, has certainly compensated the lack of child-care facilities, especially in poorly supplied regions and, a fortiori, in rural areas (box 3). Taking into account the geographical dimension tends to show that recent measures have had positive impacts in some areas by increasing the total supply of child-care for parents in paid employment. Nevertheless, recent data are not yet available to draw clear conclusions on this issue.

\footnotetext{
${ }^{12}$ The "local" dimension of child-care issues should never be underestimated, especially in a comparative perspective. It may highly lead to biased conclusions.
} 


\section{Box 3}

Child-care facilities in France : strong regional disparities, stronger spatial disparities

The variation in child-care supply between the different regions has often been underlined.

* In 1990, around $12 \%$ of under 3 year old children whose mother is economically active go to collective day care centres $(6,2 \%$ of total under 3 year old children, that is 140,000 , see table 4). The proportion of those children whose mother works is however $18 \%$ in the region "Ile de France", but with differences between Paris (33\%), the close suburb $(25 \%)$ and the rest of the region $(10 \%)$. This proportion is slightly over $10 \%$ only in the Mediterranean regions. On the contrary, this child-care arrangement is the least frequent in the regions of "Ouest", "Nord-Pas-de-Calais", "Picardie" and "Franche-Comté" where fewer than $5 \%$ of those children are concerned (source : Desplanques, 1993).

* Attendance at "école maternelle" (state school) of 2 year old children tends to counterbalance these regional differences. On average, one third of this group attend school in France (see table 1). This proportion is over $60 \%$ in Bretagne and also very strong in "Nord-Pas-de-Calais", "Pays-de-Loire", "Midi-Pyrénées", "Languedoc-Roussillon". On the contrary, it is very low (under $15 \%$ ) in "Ile-de-France" and "Alsace", "Haute-Normandie" (source : Desplanques, 1993)

* Childminders, registered or otherwise, is a very widespread arrangement in regions where the nuclear family has dominated for long and where help from family and relatives is not frequent, that is in "Centre", "Basse-Normandie", "Pays-de-la-Loire" and "Limousin". It is also widespread in "Ile-de-France", where networks of "crèches familiales" are implemented. On the contrary, this arrangement is less frequent in the South, the North and the East where children are more often cared for by a relative, notably grand-mothers (source : Desplanques, 1993).

* The use of an employee at home is quasi in-existent in "Centre" and "Pays-de-Loire". It is most common in Paris, in the two richest departments of the Paris conurbation, "Hauts-deSeine" and "Yvelines", and to a lesser extent in the Lyon conurbation (Fagnani et Rassat, 1997a).

If disparities between regions are strong, intra-regional or intra-departemental disparities are much stronger, especially between rural and urban zones, as shown by the concentration of collective child-care facilities in urban communes, especially the biggest ones. The presence of such facilities in the neighbourhood is actually determining on the choice of such arrangements. Apart from some local studies or monographies, there are however few sources on these spatial disparities. A survey led in the "département" of "Meurthe-et-Moselle" (Lorraine), shows that one third of under 3 year old children are cared for in collective facilities in communes over 10,000 thousand inhabitants while the proportion is only $3 \%$ in rural communes (Guillot, Jankeliowitch-Laval et Reinstadler, 1997). On the contrary, more than $70 \%$ of those children are cared for by a childminder in rural communes, but only around $30 \%$ in urban communes. This survey also shows that, independent of the size of the commune, the child-care costs for each arrangement vary greatly from one area to another (Guillot, Jankeliowitch-Laval et Reinstadler, 1997).

\section{Priority to an employment policy of low wages and high public subsidies...}

The targeting of policy measures towards individual child-care facilities and average/high income families, follows a certain economic logic. It reflects the overwhelming idea that it would be a more efficient way to create jobs in child-care, especially in a context of social expenditure restrictions. It actually makes the supply less onerous and boosts the demand through the incentive of subsidies. 
In an employment policy perspective, collective child-care facilities are considered as too costly compared to individual child-care arrangements, notably because of their higher requirement in the quality of services (facilities, number of employees with a qualification and guaranteed wages). The jobs of employees in the home and of childminders are precarious, low paid, of limited duration, most often part-time, with flexible hours and with few prospects, that is, are in line with the current labour market trends (Causse, Fournier et Labruyère, 1997). Strong public support for carers' employers, especially through social contributions exemptions and generous income tax credits (see supra, figure 2), is considered a solution for the creation of employment. Targeting public resources on families that can afford an individual formal child-care certainly appears efficient from a rational economic point of view.

\section{... with rather disappointing results.}

The current results do not seem to confirm completely these expectations. The official Cour des Comptes has criticised, in its 1996 report, the public cost of the creation of jobs in the home. Arguments about the creation of jobs and of their public cost are raised since only 10,000 equivalent full-time jobs (20,000 employees) have been estimated $^{13}$. Moreover, a recent survey of AGED recipients shows that a large proportion of the families, especially the richest ones and/or with very demanding professional obligations, would have employed a person even in the absence of AGED and tax credits (Fagnani, 1997b). Other comparative research has shown that a policy of low labour cost in the child-care service market is certainly not an adequate solution for matching/meeting employment objectives, especially in a sector totally shaped by very specific national contexts and where international competition is totally absent because of the necessary local feature of child-care facilities (Sauviat, 1996).

\section{Working conditions of employees in the home?}

A recent survey highlights the labour conditions of employees working at AGED recipients' homes (Fagnani, Rassat, 1997b). The family employers, mostly well-off dual-earner couples, have high requirements on the employees who are quasi exclusively women. Since both parents most often have very high professional constraints, the employees have frequently to work in the home up to 10 or 12 hours a day, five days a week, earning only the monthly minimum wage (a part of the time spent at home is not considered as full-time paid work). Labour legislation is not very favourable for employees in the home and they are paid the very minimum. This child-care arrangement is very convenient for recipient families since the child-carers most often fulfils other duties, such as keeping the house, preparing the meals for the employers, etc. A majority of the employees are young women with their own family obligations. Given the long time the carers have to spend at recipients' homes, it may be ironic to restate that AGED is officially aimed at the "reconciliation" of family and professional lives. Furthermore, employees do not benefit from training or any real professional prospects. On the other hand, domestic helpers, previously working in the

\footnotetext{
${ }^{13}$ This estimation dates from 1994 before the important increases of AGED and tax credits. The real figure may be three or four times higher in 1997, remaining in all cases at a rather limited level.
} 
black economy, benefit from legal protection and social insurance coverage, in particular for health, working injuries and retirement. For foreign women or women with foreign origins, these jobs also constitute the very few current opportunities on the segregative labour market.

\section{The very recent measures : modifications at the margins, not fundamental changes}

In a context of budget restrictions and social security deficit, the measures in favour of well-off families utilising employees in the home have appeared shocking and have been highly criticised (Fagnani, 1997b). For instance, the official committee of the "Conférence sur la Famille" (Conference on Family) in its final report, published in February 1997 during the former right-wing government, asked for a limitation in the advantage given to better-off families (Gisserot, 1997). Without changing the global logic, the new socialist government decided to decrease the amount of AGED by $50 \%$ for recipients earning over 25,000 F per month and $25 \%$ for other recipients who would represent between a fifth and a third of recipients ${ }^{14}$. The tax credit will remain equal to half of the total expenditure, but the maximum is lowered from $45,000 \mathrm{~F}$ to $22,500 \mathrm{~F}$ per year : this limit remains nevertheless very high such that only $5 \%$ of households would see their tax credit limited to this amount.

These new measures, that should be implemented in 1998, tend to attenuate slightly those aspects of child-care policies which were the most shocking from a redistributional or social justice point of view. Nevertheless, the changes are effectively small : the total advantages for AGED recipients remain higher than they were in 1993 during the previous socialist government ${ }^{15}$. The trends should fundamentally be the same and the previous evolution should continue in the childcare sector.

\section{The long road towards a care services policy for dependent elderly people.}

It is generally considered that the Laroque report of 1962 marks the beginnings of a true French policy for the elderly that would go beyond the initial objective of assistance to old people. This report advocated a policy facilitating the maintenance of elderly people at home. The aim was to promote good integration of elderly people, especially able-bodied ones, in their environment, in order to avoid their isolation. This resulted in the slow implementation, during the 1970s, of certain proposals recommended by this report : adaptation of housing, organisation of leisure for elderly

\footnotetext{
${ }^{14}$ Actually, the socialist government wanted initially to diminish AGED by $50 \%$ for all recipients. This proposal encountered a rather unexpected strong opposition, that could be explained by the fact this proposal was taken together with the very controversial decision of means-testing the previous universal family allowances. The socialist government had actually to face a strong and well organised opposition composed of right-wing political parties, conservative trade unions, conservative and powerful family associations and even the communist party ant its allied trade union, together with the tacit support of many influential journalists and powerful "hauts fonctionnaires".

${ }^{15}$ While the Ministry in charge of the social protection in 1997, Martine Aubry, was already in charge in 1992-1993.
} 
people, development of home-helps, sheltered accommodation centres with medical care, creation of medical therapy establishments.

Two laws were passed in 1975 : one regarding handicapped people, with the creation of the «allocation compensatrice pour tierce personne » (compensatory allowance for help), the other relative to medico-social establishments. They have been of paramount importance for the care of elderly people. In 1978, long stay units in hospitals were implemented together with a special double tariffs, a part chargeable to the health insurance of the Social Security fund, another part to the person concerned and/or their descendants or to the «aide sociale». At that time, there began a discourse of dependence or of «people having lost their ability to accomplish essential acts of daily life ». A parliamentary report utilised for the first time in its title the expression « dependent elderly people».

An assessment of the different measures, made in 1980 in preparation of the «VIIIème Plan » and synthesised in a report labelled «Vieillir demain » (become old tomorrow), is globally negative : lack of home help services, quasi-absence of real adaptation of housing, unjustified hospitalisations in short-stay units or in psychiatric units, lack of social establishments with adequate medical care, inadequate caring in long-stay units that were sometimes considered as «mouroir» (a place to die more rapidly), over frequent breaks and incoherence of health and social caring, etc. In 1981, a first State secretary for pensioners and elderly people was created. In 1982, a regulation (« circulaire Francheschi ») aimed at better co-ordination and adaptation to needs and of the service supply, by setting up in each «département» (county) gerontological plans elaborated jointly between the State and «conseils généraux » (local governments). This situation remained globally stable till the beginning of the nineties.

Contrarily to what happened in the field of child-care policy, very few innovations happened during the eighties and the very beginning of nineties in the policies towards dependent elderly people. First, we will present the main figures of the situation till the mid 1990s : number of dependent elderly people, main formal services and allowances and informal care. Second, we propose to analyse the French political debate surrounding the issue and the nature of the change beginning in 1994 till the present.

\section{II-1. Formal and informal care of dependent elderly people : situation at the beginning of the nineties}

\section{II-11 Number of Dependent Elderly People : controversial statistics}

As with many European countries, France is concerned by the growing percentage of elderly people, and particularly of frail elderly people. There is a variety of data concerning the total number of dependent people in the French population, regardless of whether their care is long-term, professional or informal. In fact, dependency is dealt with target population by target population.

The quality of the statistics concerning the dependency of elderly people remains limited, despite the topicality of this problem. Estimates of the numbers of dependent 
old people vary from one official report to another, from one statistics institute to another, according to the criteria of dependency used. The enquiry by INSEE on French living conditions, the ten-yearly INSEE-CREDES enquiry, all the CREDES work on old people in institutions, the INSERM work which has undertaken the aggregation of the results of several regional enquiries supported by the same methodology, the SESI (the statistical arm of the Ministry of Social Affairs) enquiry into establishments sheltering elderly people (Statistic Document, December 1992), the «Caisse Nationale d'Assurance Vieillesse des Travailleurs Salariés » (CNAVTS) (social security pension funds) study on the cost of dependency of the elderly (Bouget et alii, 1990), all constitute the main sources on the numbers of dependent old people.

The concept of dependency can be split into many subdivisions since the problem is to detect an incapacity which necessitates help from a third party. The incapacity can be defined theoretically (the potential capacities of the elderly person) or practically. In the same way, the need for assistance will be understood differently by professionals (who emphasise norms often close to those recommended in institutions or in the hospital environment), by the family (who will stress the behaviour and the former lifestyle of the old person, concerning for example, personal hygiene and mobility), or by statisticians (who are interested in demand for services). In any case, dependency should not be thought of as a fixed state ; it is a question of a process capable of being modified in its evolution, of being anticipated, or of being reduced in its effects by an adapted environment or services. Hence, it must be considered that the total number of elderly people with dependencies is unknown and a certain degree of approximation in the evaluation of their numbers assumed ${ }^{16}$.

The classification of dependent elderly people proposed by INSERM, taken up by SESI, allows us to make some estimates, with a certain margin of error concerning the number of dependent elderly people. At the beginning of the nineties, out of 7,530,000 people elderly over $65,1,500,000$ (maximum) are reported to be dependent in varying degrees (Shopflin, 1991; Colvez, 1990) of whom 550,000 need outside help to cope with the activities of daily living, such as eating, dressing, washing, moving around their accommodation.

Elderly people confined to bed or chair (source SESI)

290,000

Elderly people not confined to bed or chair

but needing help with washing and dressing (SESI)

Elderly people unable to leave their home unaided (source Colvez)

370,000

between 830,000 and 975,000

Table 1: Estimate of the Number of Dependent Elderly People in 1990

In 1996, 2,200,000 homes have at least one frail elderly person at home. Half of these family homes declare at least one outside help for the care of the dependent people. 870,000 homes have professional support paid for by themselves or by the public services (40\%), 320,000 receive a non-professionalised help, most of the time for free.

\footnotetext{
${ }^{16}$. The national institute of statistics (INSEE) has a project of a sizable national enquiry on « handicap and dependency» which is not realized yet. This absence of a national enquiry is even more problematic in the case of short and middle-term projections of dependent and elderly people, unless one chooses the reasoning that "other factors unvarying", in other words, only taking into account the demographic variable, and disregarding the progression of the incapacity of elderly people and the transformations which can happen as a result of the consumption of health care.
} 


\section{II-12. Formal Care Services}

Here, the distinction will be between long-term care in institutions, and that of the home-help services, whose main function is the support of voluntary carers, and the domestic or informal production of care (Joël, 1997).

\section{Long-term care in institutions}

Category of establishment

1. Long-stay units in public hospitals

2. Public hospital sections without medical care

3. Public hospital section with medical care

Number of units Number of patients

$800 \quad 60,000$

257

19,873

820

80,455

Autonomous establishment

4. Retirement homes

without medical care

2,200

94,085

5. Retirement homes with medical care

1,735

138,085

6. Sheltered accommodation without medical care

2,392

129,293

7. Sheltered accommodation with medical care

8. Temporary accommodation centres

9. Other permanent accommodation establishments

Total

Table 2 : Residential Accommodation for Elderly People (source SESI 1990)

The number of elderly people in institutions has increased between 1990 (table 2) and 1996 : they were 630,000 at the end of $1996 ; 395,000$ in retirement homes and 153,000 in sheltered accommodation (whose 130,000 with medical care) and 78,000 in long-stay units in public hospitals. Of these elderly people in institutions, $25 \%$ depend on what is called the «aide sociale départementale» (a means-tested allowance which the local government may reclaim from the relatives submitted to legal obligation). This number has proved relatively stable for years, despite a small reduction : 162,000 in $1984,143,000$ in $1989,140,000$ in $1991,138,000$ in 1994 . The proportion of frail elderly depending on «aide sociale » in institutions varies between the «départements » : from 45 frail elderly people (for 10,000 people more than 60) in the «Vosges » to 206 in the Paris conurbation, or 220 in Lozère (the mean for France is 119 for 10,000 people more than 60 ).

\section{Foster Families}

A law of 1989 authorises the reception of elderly or handicapped adults into private homes for financial gain, provided agreement is given by the president of the county council (Conseil général du département) and that a contract is drawn up between the person and the family receiving them. The person fostered can apply for social assistance and allowance from the housing department. Inspections of the service and 
the charges, as well as a medico-social backup, are organised in the household where the care is provided. This formula, which indicates a change from the model of "professional" French aid, has allowed people to regularise a situation which already existed, but it has not met with great success and its growth is slow. 500 elderly people were concerned in 1990, only 810 in 1994. It is still a very marginal formula.

\section{Formal Support at Home}

A whole series of medico-social services intervene at home to support volunteers, or more precisely family helpers or the main carer (mainly women of the family network : spouses, daughters, daughters in law, etc.), who supply nonetheless the greater part of aid to the dependent person. These are the home-helps («aide-ménagères), care assistants («auxiliaires de vie »), district nurses (« services de garde à domicile »), the carers and different neighbourhood services.

In 1996, professional help (aide-ménagère, auxiliaire de vie, garde malade, nurses, etc), received by the families with at least one dependent person at home represents more than 400 million hours per year, which corresponds to an equivalent of 220,000 full-time jobs, compared to 230 million hours per year for informal support offered by the environment of proximity (mainly in the family network). At that time, the global cost of the dependence supported by the families was more than 8 billion francs. But this cost varies substantially given the individual case. For many families, these costs are completely assumed by the collectivity. Those who have to pay for professional services are about 630,000 , or $28 \%$ of the families with at least one dependent frail elderly person at home. Even so, 25\% of these families pay less than 160 francs per month, compared to a mean cost for these services in a family of around 1,000 francs per month, which means that the collectivity reduces substantially the cost of these services for the families with low resources.

Home-help service ("aide-menagère") : It is the most developed of the professional help. In 1990, 80,000 home helpers (or the equivalent of 40,000 full-time jobs) offer, in the homes of dependent people, "material, moral and social support which contributes to maintaining them in their home", as indicated in the collective convention of 11 March 1983 (Kerjosse \& Lebeaupin, 1993). In 1988, 74 million hours were attributed to 490,000 elderly people (less than 12 hours per month). Only 20,000 people receive both home help and health care at home, which demonstrates that the service is not aimed at the very dependent. This service, because of institutional rigidity, does not provide a great deal of support and does not supply sufficient aid to dependent people to enable them to carry out the activities of daily living. This aid is distributed by "non-profit" associations or private status services for $62 \%$ of the hours, or by ( « centre communal d'action sociale ») communal centres for social action for $32 \%$ of the hours. The financing is provided either by the elderly people themselves or by retirement funds, in particular the social security pension funds (44\% of the total hours), or by "département" social welfare in cases where individual income is insufficient (29\% of the total hours). In 1994, within the framework of the CNAV, 331,000 elderly people benefited from 33 million hours, or 8.5 hours per month. For an average hourly cost of 58 francs, this represents an expenditure of 1.9 billion francs. 
The other social and medico-social services are numerically less developed and little is known about them, both because of their experimental nature and the speed of their evolution, and because their financing makes use of a complex inter-institutional setup.

Care Assistants ("auxiliaires de vie") : Created in 1981, the care assistant helps the frail elderly and handicapped people in their daily life. In 1992, more than 250 services employed 4,000 care assistants (which represents 1,800 full time jobs). These care assistants realised 1 million hours and helped 13,000 people or families. $60 \%$ of the beneficiaries are elderly. The state subsidises 1,800 care assistant posts each year. Local authorities and social security agencies can provide backup financial support, and associations and communal social action centres provide the service (cost : 0,12 billion francs).

District Nurses ("gardes à domicile") : District nurse services (non profit-making associations) have had difficulty developing due to the high level of finance required. Financing which exists by way of the «allocation compensatrice pour tierce personne» (compensatory allowance for a third party, see II-1.4), exemption from taxes and fiscal allowances and all the recent measures which favour "jobs of proximity" contribute to the direct financing of district nurses by individuals. Since 1 January 1992, the CNAV created a district nurse service allowance whose use has risen relatively quickly from the first year of operation (14,318 beneficiaries in 1992 ; 23,000 in 1995). Each beneficiary has received an average of 4,378 Frs and the total expenditure of the CNAV has gone up from 60 to 100 million francs. Most of the finance for these nurses still comes from the resources of the elderly person or their family. Very often the families, rather than calling in the services of district nurses, take on a domestic employee, "arrange things with the neighbours" or resort to blackmarket workers.

Neighbourhood Services: The last ten years have seen a multiplication in very varied neighbourhood services : meals on wheels, canteens for elderly people, collection and washing of dirty linen, tele-alarms, tele-assistance and tele-contact ; home maintenance service; S.O.S. repairs; companions for going out, sitting services at home; home delivery of medicine. These services are provided, according to the locality, by boroughs, elderly persons' clubs (clubs for rural old folk), associations ("secours populaire", Brothers of The Poor, The St Vincent Teams, The United Jewish Social Funds, "Secours Catholique" ...), or the private sector. They are financed by the user under the form of a lump-sum contribution, from resources resulting from donations to associations, or subsidies from local authorities. Public authorities have actively encouraged the development of these "proximity services", by means of exemption from social security contributions, largely because they are expected to create jobs with relatively low qualifications. Social services have introduced a number of innovations to assist the elderly. These innovations are basically of three kinds:

- the application of information technology, notably in the area of tele-surveillance.

- better public information : data banks with details of accessible establishments and free places, software allowing elderly residents to manage their financial situation.

- finally, a softening and diversification of assistance, for example, introduction of ergotherapy into nursing care; numerous experiments of co-ordination of services at 
home ; extension of home helps in certain counties; loans or grants for housing improvements; transport allowances; free or half-price passes. The CNAV (with an expenditure of 18 million in 1994 in innovation to assist heavily dependent people) and the Foundation of France have contributed to financing these innovations.

\section{II-13. Informal Care}

Until recently and contrarily to what happens in many foreign countries, politicians, as well as researchers, have paid very limited attention to the question of nonprofessional care and to that of the carers. French literature deals mainly with professional care, with very few exceptions. Several reasons can be advanced to explain this fact. In the first place, the economy of health is structured in France around the analysis of care and a "Pasteurian" vision of medicine is imposed (a good diagnosis, adapted care and rapid cure), which forces the study of long-term care into the background. Secondly, the policy towards the elderly in France until 1970, was mainly concerned, and successfully, with raising the incomes of the elderly. In the following ten years, the desire to curb health costs led to a promotion of the policy of keeping people in the home, with the creation of numerous home-help services and care at home. Finally, in recent years, seeing that the current system of support was very stratified and lacking cohesion, the theme of co-ordination (around the person between the various concerned institutions) has grown in scale and has given rise to different initiatives, particularly at a local level (gerontological plan).

However a recent change must be noted. The economic crisis, the extent of social deficits and the scarcity of social funds have modified the perception of the social authorities. Themes such as intergenerational solidarity, help for helpers, which had not really found their place in the French social policy debate, have met with a certain success in the 1990s. The idea that social policy should not be limited to the public financing of the provision of professional care, but could also bear on the articulation between professional and non-professional care, is making headway.

Nevertheless, non-professional care remains a poorly understood phenomenon. In fact, out of 1,500,000 elderly people of varying degrees of dependency, $80 \%$ live at home, and $68 \%$ live with a close relative; $50 \%$ of those over 65 live in a couple and $18 \%$ live with people other than their partner or in addition to the latter; in total, $32 \%$ live alone (Kerjosse \& Lebeaupin, 1993). Out of the 800,000 elderly dependent people who live with a close relative, a majority receives non-professional care. But the nature and intensity of this care has yet to be analysed. The CNAVTS enquiry (dating from 1988 and including 2,136 people) showed that, among people aged over 75 living at home (whatever their state of health), 60\% benefited from the aid of their family circle for the activities of daily living and $95 \%$ of very dependent people received such assistance (see also Lesemann \& Martin, 1993 and Joël \& Martin, 1996 and 1997).

\section{II-14. Indirect Payment for Non-professional Care}

Until the reform of January 1997 (see below), creating a new means-tested allowance for elderly dependent people, direct payment for voluntary helpers by the local authorities was not developed in France. Before that recent reform, it was possible (precise information is not available on this point, except on a very local basis) that 
particular financial allowances for dependent people, and, more generally, all the funds given to the dependent population were used to pay relatives for the long-term care provided by them. Clearly, any funding of a dependent person opens up the possibility of payment for helpers. The fact remains, however, that this possibility is not always used, and that the dependent person can use his cash assistance as he wishes, in particular to give gifts, without compensation, to people close to him. This argument is often used by social services or politicians to justify the preference that they have for practical assistance or payment in services and not in cash. There are various allowances paid to the person in need of care and these will now be discussed in turn.

The main allowance payable to dependent elderly people was, until 1997, the compensatory allowance (allocation compensatrice pour tierce personne) a meanstested and income-need tested benefit paid by the département (county), of which the maximum amount varies according to the person's incapacity from around 2,000 to 4,000 francs per month (in 1992). The compensatory allowance was allocated by the COTOREP (a commission composed of different professions and experts : medicotechnical and administrative professionals), which decided, on the one hand, the placing of handicapped people, and on the other the allocation of financial assistance to them. This allowance was paid to 210,000 people over 60 in 1995, this being a little more than $70 \%$ of all recipients. The share allocated to people aged over 60 represents approximately 6,3 billion francs in 1995 . The compensatory allowance, whose cost rises constantly, was the object of severe criticism from a great number of counties. They criticised :

- the method of allocation by the COTOREP, which was particularly complicated and slow ;

- the high cost of the allowance overall compared to other social aid allowances ;

- the fact that the allowance is hoarded by the beneficiaries, who do not buy services with it ;

- and finally, the fact that the allowance is not subject to legal maintenance obligation. As the result of the decentralisation of financial support to the département, it was no longer for the départements to recover the amount spent from family on the death of the elderly person.

Furthermore, there are considerable variations between départements as to the amount that is actually paid. The average amount per person can vary from 25,000 to 40,000 francs per year : in certain counties, the compensatory allowance is given to less than $1 \%$ of the inhabitants over 60 , while in others nearly $2.5 \%$ receive it.

On top of this allowance, retirement funds pay a supplement for the payment of a third person (Majoration pour Tierce Personne) to those entitled to certain old-age benefits. The total expenditure of this payment for a third person is presently 1,3 billion francs for 21,000 beneficiaries.

In summary, the French system is quite complex, costly and badly co-ordinated. In 1991, the SESI estimated the global cost for the frail elderly to almost 27 billion : $45 \%$ to the charge of the social security Health fund, $16 \%$ to the charge of the social security pension fund, $37 \%$ financed by the counties (département). $40 \%$ of the global 
cost was oriented to the home care policies and $60 \%$ to the care in institutions. All of the following elements have opened a long debate between experts and the production of numerous reports from 1986 till 1994, which has introduced the necessity to reform the system and create a new allowance.

\section{II-2. The French political debate and the turning point of 1994}

\section{II-21. A long period of political «non decision » on elderly people dependence issues (1986-1993)}

Actually, as Kessler noticed, dependence becomes an « autonomous » issue only from 1986 because of the preparation of the Théo Braun report of the national commission of study on dependent elderly people (Kessler, 1994, 1995a). This report analyses the precise causes of dependence and the inadequacy of the measures in place. It proposes an «assurance autonomie» (autonomy social insurance) for pensioners and the provision of a benefit in kind in the framework of «allocation compensatrice pour tierce personne ». Afterwards, there follows a long succession of reports : an official one by Geneviève Laroque in 1989 (Inspection Générale des Affaires Sociales), a report by two researchers Marie-Eve Joël and Martine Bungener for the Ministry of social affairs in 1990, the parliamentary «Boulard» report in 1991, a report made by experts for the preparation of the «Xème Plan» (Schopflin, 1991). Meanwhile, five proposals of law are written between 1991 and 1993, on dependence caring and on the implementation of a dependence allowance for elderly people (see Kessler, 1995, Kerschen \& Mercat-Bruns, 1993). None of these projects ever passed.

Like Bruno Jobert, this slow process for defining a policy regarding dependent elderly people may be qualified as an «exemplary non decision ${ }^{17}$. First, the awareness of the dependence phenomenon and of its amplification has highlighted the schemes facilitating maintenance in homes which were built for active, able-bodied and participating elderly people. Actually, measures implemented since the beginning of the 1960s have been effective in helping elderly people with very low income and with low level of handicap, but they have been totally inadequate for heavily dependent elderly people. «The system is actually a set of services aimed at bringing a compensatory help, each service corresponding to one aspect of daily life : washing, medical care, housekeeping, meals... But, this always presupposes a person is mentally and physically autonomous, able to manage this set of services him/herself and to live without any external care during the rest of the time. Outside those particular duties, it is in this model, the family's or the neighbourhood's task to ensure a minimum of presence and care. It appears that this requirement of presence becomes an extremely heavy burden when one enters in the zone of senile dementia or severe incapacity. This heavy dependence happens generally with very old age and, thus, at a time, when, because of disease and of death, the number of friends and relatives that could have been able to help empty » (Idem, p.46). With the consequence of a considerable burden, which is sometimes unbearable, on the shoulders of the

\footnotetext{
${ }^{17}$. For him, there is «non decision when the necessity of a public policy is recognised as urgent in the political discourse and that, however, this repeated recognition does not result in any public action » (1993, p.49).
} 
« génération du milieu » (Attias-Donfut, 1995), or even on «third age » daughters. As Jobert states, "everything happens as if society had assigned to the 'third age' the function of caring for the 'fourth' »(p.46).

Francis Kessler (1995a) has summarised the main orientations of the proposals made from 1986 to 1993 in the reports and law proposals, mentioned before. According to him, they concern two types of issues : the «solvabilisation » of elderly people and the promotion of a better organisation in the supply of services.

1. On the first issue, the «allocation compensatrice pour tierce personne » (ACTP), one of the main measures relative to dependence, initially conceived rather for handicap problems, is criticised for two principal limitations : firstly, the slowness for the payment and the imperfection of the criteria for entitlement, and, secondly, the fact that this benefit (paid most often well in arrears) is not utilised as it should by recipients who are suspected of accumulating the amounts on their saving accounts rather than financing the services necessary to their daily life. The idea proposed for solving these problems consists of a new benefit that could be paid rapidly, with an income-related amount that would also differ according to the degree of dependence. Depending on the various reports or law proposals, the benefit should be in kind or in cash. Because of its individual and subsidiary features, this benefit would keep on following a logic of assistance («aide sociale»), but experts' arguments generally converge for not maintaining a logic of pure assistance, notably by removing family maintenance obligation. The development of a private insurance scheme that could complete the public answers is hardly evoked. But the possibility of a social compulsory insurance solution has been instantly discarded without any justification. Eventually, the logic would remain a logic of « aide sociale », i.e. targeted at the most disadvantaged.

2. On the issue relative to the organisation of services, it is proposed to improve the conditions of sheltered accommodation in establishments, to better coordinate the interventions, to diversify the supply of services and to raise the paradoxical situation where caring in establishments is less related to the level of the concerned person's dependence than to the status of the establishment (medical, shortstay, long-stay, psychiatric units). It is recommended to co-ordinate action at a local, or even micro-local, level, in order to invite the different actors to collaborate (social workers, doctors, nurses, home-helps, care assistants, administrators of local governments, of Social security «action sociale », of services of the «departements », etc).

One of the main stumbling blocks, perceptible in those different plans, is the financing, which has been till now the responsibility of «départements », social security funds («Caisse nationale d'assurance vieillesse» and «régimes complémentaires »), with a small contribution from the State, not to mention the families' major contribution. Only a solution involving many actors in financing appears as acceptable at this time, in a context where nobody has been able to estimate the cost of such a policy, notably in reason of the lack of knowledge about the number of dependent elderly people (see supra, II. 11). One can argue that these approximations serves as political arguments whether to impose the imperative 
necessity to define a new policy, whether to argue for the necessity to wait for a better evaluation of the problem, before any decision.

The obstacles stem also from the different governments that succeeded during this period. «Those repeated delays may be explained by the strong reticence inside the government for opening the gates to an expensive policy whereas the control of public expenditure was considered as a key element of the economic strategy... It appears much easier politically to refuse a new policy than to do the housework inside already instituted policies » (Jobert, 1993, p.51).

Francis Kessler underlines the insufficiencies of the French debate, but also the paradox of a situation where a social insurance option as part of a caring policy has been discarded without any discussion, especially in the case of elderly people having contributed a large part of their life to social security funds. The recommended policy consists of a social assistance option (for the poorest), the recourse to the family, and even to the market (for the others). He also criticises the usual way to consider the problem through a target population, making dependence a problem of old age, contrarily to systems in countries like The Netherlands or Germany, where dependence is considered whatever the age. The different reports and plans, which all seem to go back to the traditional assistance options of the 1893-1963 period, do argue badly for future reforms, according to Kessler. That is the reason why he criticises in advance the recent choice of experimenting with a new system in 19951996, without a true background discussion (1995a, p.94, 1995b).

One must recognise that the partisans of a social insurance system have been unable to make themselves heard by decision makers during the period. The room to manoeuvre was very small and this was in favour of a «reformist» perspective for any new scheme rather than for the creation of a «new social risk», i.e. dependence, that would have supposed a more radical disruption of the whole social protection system. Everything has happened as if the government's room to manoeuvre was so reduced as the sole alternative consisted of «kicking the ball in touch» and mobilising local resources and making actors, more motivated for a reform, to co-produce public action.

\section{II-22. The choice for experiment : a policy window (1995 - 1996)}

Due to the numerous obstacles already mentioned, the French choice consisted of promoting, by means of an experiment in some areas, some of the last reports' proposals and the principle of an evaluation before setting up any generalisation on a national scale. Edouard Balladur 's government chose to mobilise first local policy makers and actors willing to reform the existing elderly people care system. It also avoids formulating any principles and norms that would not gather a consensus at the local level. Like for the implementation of « revenu minimum d'insertion » (minimum guaranteed income), experiment and evaluation have been the two central modes for defining an applicable social policy.

This kind of choice stems obviously both from the new principles set up by decentralisation laws of 1983 and from the transformation of needs and social problems in the context of Welfare State crisis. This logic of experiment attempts to 
make various public interventions coherent rather than to propose a standardised topdown model of public action. Experiment creates the conditions for a mobilisation of the local actors by delegating to them the definition and content itself of the policy, and the necessary references for actions.

The law $n^{\circ} 94-637$ of 25 July 1994 has set up the principle of the experiment of a dependence benefit at the «département » level for dependent elderly people living at home. Those experiments started in January 1995 in twelve «départements » for an initial period of one year (extended to two years), by means of conventions between different actors : «conseils généraux » (counties local governments), Social security local administrations, territorial collectivities, representatives of the State, according to directives established by the Ministry of social affairs, in concertation with representatives of the "Caisse nationale d'assurance vieillesse » (national social security pension fund) and the association of «conseils généraux » presidents (APCG).

The directives define the characteristics of those experiments, as a reference for the « départements » and assigns a certain number of goals : validating a schedule for evaluating dependence ( grille d'évaluation de la dépendance »); implementing a true co-ordination by informing the elderly person and his/her family of available services and help and orienting them ; promoting at the « département » level a better adjustment between care supply and demand ; appraising the number of eligible people and the total cost of care dependence.

The «experimental dependence benefit» (prestation expérimentale dépendance PED) is composed of two distinct, complementary or alternative, benefits : the existing «allocation compensatrice pour tierce personne» (ACTP) paid by the «conseil général » of the «département» and a supplementary dependence benefit («prestation supplémentaire dépendance » PSD) chargeable to the social security pension fund. Both are means-tested. The ceiling for ACTP is the taxable personal income of 3,200 francs per month for a lone person and 5,700 francs for a couple. The ceiling for PSD is the taxable personal income of 4,800 francs for a lone person and 8,600 francs for a couple. As a whole, the total maximum amount of PED was 4,264 francs per month in 1995. Almost 2,000 recipients received that new benefit, for a total amount of 18 million francs in 1996.

The experimental scheme is characterised by several principles relative to coordination of services (centralisation of information, implementation of social and medical teams, etc.), evaluation of dependence, etc. The main originality of the scheme comes from the «contrat d'aide à l'autonomie» (contract of help for autonomy) between the payer(s) and the recipient. This contract stipulates the human and material means used for compensating dependence needs, the cost of those services, the rhythm of intervention and co-ordination of the different professional actors. It is aimed at putting responsibility on the elderly person and his/her family, by insisting on engagements from their side. It is, to a certain extent, also a means of 
communication between actors as well as a guarantee to control the effectiveness of help ${ }^{18}$.

\section{II-23. The option for a professional, « do-it-yourself » and a pro-active policy}

Together with the prime interest in satisfying caring needs, another preoccupation, in keeping with local politicians' views, has been rapidly considered as of primary importance : employment. Currently, improving help and care to dependent elderly people also corresponds to the political will of encouraging potential « gisements d'emplois » (source of jobs), that is, relational services, family employment, even if many criticisms have emerged for underlining the extent to which those are pseudojobs, under qualified, underpaid and under protected. Those «small jobs» are occupied quasi-exclusively by women and are often «transformed», even presented in discourse, for political reasons in «equivalent full-time» terms. The experimental scheme has favoured the direct employment of non-qualified persons to give the help and care in the home of the elderly, destabilising the professional help sector, mainly the home-help services.

A more positive aspect of the experiment stems from the collective learning of the procedures by the different local actors who have built together the modes of action and had to negotiate, discuss and stabilise their practices. The assessment of the experiment has revealed this very central role played by certain local actors who, either at the level of the socio-medical and administrative dependence technical team («équipe technique dépendance»), or at the level of the co-ordination in the « départements », have implemented the « contrat d'aide à l'autonomie » (contract of help for autonomy). Those different levels of the scheme may be considered as the places where, in the framework of the actual practice, the effective norms have been elaborated. They have been adjusted taking account of both professional (and often stringent) requirements and the necessary flexibility for adapting answers very closely to the very diversified needs of the population (elderly people and their families). From this point of view, one may speak of learning, or even innovation, at these levels.

Since this experimental system has consisted of cash benefits, it has been possible to adjust the answers to people's needs, in accordance with their ways of life and consumption preferences and practices. According to their own logic, recipients can either internalise the aid inside the family (by encouraging informal care or by employing and paying directly a member of the family), or externalise towards professionals (by recruiting directly or by using home-help formal services employers). This greater choice has however also resulted in the need for control, especially to check that the benefits are not accumulated on saving accounts.

The experimental scheme has privileged a very decentralised management, close to the elderly person's needs. This has permitted better-suited answers, rather than overly normalised ones. This case by case management has however necessitated a very

\footnotetext{
${ }^{18}$ We realised the evaluation of this new scheme in one of the 12 counties : Ille et Vilaine in Britannia, see C. Martin, A. Jourdain, F. Mohaer, F-X Schweyer (1996). There were 41 « départements » volunteer for the experiment among a hundred or so.
} 
strong engagement from the professionals in charge of the co-ordination and of the adaptation of answers. These latter conditions were no longer met at the end of the experimental phase, since most professionals, especially social workers, stated that they had to renounce their usual, other functions and tasks in order to deal exclusively with the implementation of the new scheme.

The experiment has also raised the important problem of territorial equity. An extension in all «départements » of such a demanding scheme for local actors may lead to very important territorial inequalities. The experiment has shown in areas with a long-standing tradition of collaboration a real and effective, while unequal, mobilisation of local partners. But it is obvious that the conditions of such success are much more problematic, or even not possible, in other « départements ».

The experimental phase has eventually left open the question of the next step(s). Several questions have been raised. How to prolong the investment ? How to make partners continue mobilising as has already happened in the learning phase by social workers? Which means have to be found to maintain the quality of care ? What about the visible consequences on care in institutions, especially questions about the cost of such services? Until recently, all these questions were suspended to the government's decision which was awaited for more than two years. As time passed, the risk of demobilisation of the local actors involved increased.

\section{II-24. Critical overview of recent evolution.}

The creation of a new allowance for the dependent elderly people was one of candidate Chirac's main promises during the last presidential electoral campaign. It was also one of the points of the declaration of general orientations (déclaration de politique générale) of the Prime Minister Alain Juppé, the 23 may of 1995. A bill was prepared by the government, before the evaluation of the experimental phase, but the problem for financing the project, and the opposition of many members of Parliament has delayed the adoption of this project. Because of the discontinuity in political life, the recent decisions have not really taken into account the lessons drawn by the territorial experiment, neither discussed the options.

During the second year of the experiment, a hidden fight divided the social security system specialists and politicians, mainly those who cumulate in France a national and a local mandate, about the future of the scheme and the directions of the future law. The presidents of local governments (Conseils généraux) regrouped in the «Association des présidents de conseils généraux » (APCG) won this fight in a way, obtaining a minimal and temporary scheme, which proposes to use the global amount of the «allocation compensatrice pour tierce personne » for the new allowance, and to keep some advice and principles of the experiment.

The recent law rather reflects this « wait and see » position, and a «non learning », an ignorance of what the several territorial experiments have already taught. Despite numerous promises, the real choice is indeed still delayed with the new law passed in January 1997, as illustrated by the title itself : «Law $n^{\circ} 97-60$ tending, waiting for the vote of the law setting up an autonomy benefit for dependent elderly people, to better 
answer to the needs of elderly people by implementing a specific dependence allowance » (Journal officiel, 25 janvier 1997, p.1280-1284).

So, the Parliament has adopted a new law creating a new allowance («prestation spécifique dépendance » ou PSD) which concerns about 700,000 people more than 60 years old, who need help to stay in their homes, and whose resources to acceed to the maximum rate, are below 6,000 French francs per month for a lone person, or 10,000 for a couple, including the allowance (that is mainly people on social assistance, recipients of «minimum vieillesse »). The maximum amount of the allowance is around 5,600 francs per month depending on the degree of dependency (and on the means). The PSD will bring about a recovery on inheritance when its global amount is higher than 300,000 francs. This allowance will replace the «allocation compensatrice pour tierce personne ». The PSD is attributed by the county (Conseil général des départements) after an assessment of the needs by a medico-social team, and with the formulation of a contract (« contrat d'aide ») with the family, the local authorities and the providers of the help (Elguiz, 1997).

This new law gives rise to many controversies (an appeal to the «Conseil constitutionnel » by left wing deputies) because of the inequalities created between regions. Each county currently has the possibility to give more than the minimum defined by the law. So the richest counties (with a good economic performance), which are generally the least affected by the ageing of their population will have more possibilities to help them than the poorest, which are more often rural and with a higher proportion of (dependent) elderly people.

The decrees necessary to implement this law are very recent, and the implementation has just started, but we already know that the new scheme is implemented at very different speed depending on the counties, and that the problem of co-ordination and co-operation is often very deep. A strong opposition comes from many partners : directors of retirement homes and establishments, unions and associations of retired people, associations of home-help services, etc., who denounce the logic of cost maintenance and of assistance. The French orientation seems to be a waiting attitude, against all the promises and even the advice of the European council (Long, 1997 ; Kessler, 1997).

\section{II-25. French policy of care services for the elderly : A few lessons}

As far as caring for dependent elderly people is concerned, one crucial point remains to determine who should be chargeable to : the State, the social security, local governments, the dependent person him/herself and/or his/her family, with or without the recourse to facultative private insurance ? As this question concerns the core of each national system of social protection, a strong debate opposes supporters of a social insurance choice and others that prefer «aide sociale», or even assistance, together with the principle of subsidiarity (mainly family obligations), and possibly with a dose of facultative private insurance.

Several European countries have already engaged important reforms. Germany has introduced in April 1994 a «new risk» in its social insurance system. It is also the case of Austria in 1994, and might be soon the case of Luxembourg (Evers et alii, 
1994; Hinrichs, 1996). In another perspective, the United Kingdom has implemented a new policy in 1993 with the Community Care Act which raises the problem of the capacity of territorial management (promoted by the Conservative party with the introduction of quasi-markets) for reducing public expenditure in this field (Lewis \& Glendinning, 1996). France represents another totally different configuration, characterised by current indecision. Twenty years of debate, official reports and proposals of laws have not been sufficient to raise the obstacles. In spite of a consensus on the urgency to answer the demographic stakes, especially the ageing ones, on the insufficiencies of the existing system and on the necessity to reform it, it was not possible to elaborate a policy, all the same promised, announced and delayed so many times (Martin, 1998).

Several obstacles may explain this. The first one is obviously the financial constraint. In a context of the limitation of public expenditure, it is difficult to promote a policy in a field where the needs, the concerned population and, consequently, the costs are badly appraised. The second obstacle is less straightforward because it has to do with the more general orientation of reform for social protection. Behind the debate on dependence emerge the crucial choice «social risk » versus assistance and minimum protection of the poorest, with many consequences in terms of management and financing. In the face of such difficult choices, Edouard Balladur's government proposed to test a new scheme in a few counties, which has been prolonged in 1997, with a temporary law at the national level.

Such territorial experiment represents a particular conception of public action. This is a model that has less to do with what used to be called public policy, than with what P. Duran and J.C. Thoenig (1996) qualify as an «institutionalisation of collective action ». In this territorial model of public action, the State has to redefine its role, by promoting capacities of negotiation, by deciding minimum rules and by leaving more and more the «territory» to define the public issues. Such a choice also follows the letter and the spirit of decentralisation which has given the competence for «aide sociale » to « départements ». Nevertheless, other choices should have been possible, as the one of truly debating the (social) insurance hypothesis.

The model of public action could be qualified by case management, in the sense that a case by case approach is privileged, with a considerable weight given to local actors who detain the access to this complexity/singularity and who have to manage it. One may think that this model of public action will spread to other social policies, especially when one brings together recent policies such as dependent elderly people, « revenu minimum d'insertion » (RMI - guaranteed minimum income) created at end 1988 , and «politique de la ville » (policy of the town). The notion of a contract with the recipient is a significant element of these new policies. The fact of formally elaborating a contract, «contrat d'aide» for dependent elderly people, «contrat d'insertion » for RMI recipients, is not of utmost importance for the contract in itself. The fact that this contract has, or has not, the value of a contract from a strict juridical point of view does not matter much. What is important is the use of the vocabulary relative to a contract, that aims to give the recipient as well as the local actor(s), a feeling of responsibility and reciprocal engagement. 
As far as gendered effects are concerned, it already appears very clearly that the experiment as well as the new law result in a precarious situation for professional home-helps, almost exclusively women, who are now much more often directly employed by elderly people and are not wage-earners of local public services. This evolution has not been compensated by the promised effort of training for newly recruited employees. For families involved in an old parent's caring, and, actually, for women who do care for (wife, daughter, daughter-in-law, etc.), the gain is still to be confirmed. Will the new scheme bring more support ? As the last reform targets only a very low number of (poor) people concerned by caring problems, a large part of concerned families are left out of any public support. 


\section{General conclusion}

Since the beginning of the 1990s, the rationales behind caring policies for elderly people and for young children have drawn much closer due to an external stake, central to public action today : the problem of employment, or rather of unemployment. In short, one can say that caring services constitute globally a potential source of jobs («gisements d'emplois») that public authorities have attempted to shape and structure. Furthermore, the central role of families in the provision of care for dependent elderly people have emerged in the discourse of the 1990s. This new awareness has had the consequence that intergenerational relations and dependence issues are now increasingly included in the frame of family policy. The recent « Conférence de la famille », initiated by the former government of Juppé, after the new reform plan for the Social Security («plan Juppé »), publicly expressed the integration of both issues, early childhood and elderly dependence, as two essential components of the national family policy.

Despite the fact that both fields have drawn closer, differences remain important between early childhood and elderly people dependence. Currently, a series of measures and laws for child-care provision were taken during the 1980s. They have aimed at structuring and reinforcing both quantity and quality of care provision. On the contrary, the question of caring for elderly people has given rise to an important «intellectual production» (official reports, experts' reports), to proposals of law that were never passed and, eventually, to a true political «non decision ». For nearly 15 years, all political parties and experts came to the conclusion that the situation regarding the care system for elderly people, especially in matter of «home maintenance », was ineffective and unsatisfactory. Although they underlined the necessity to reform the system, everything remained at the planning stage.

It is only since the last presidential campaign in 1995 and from candidate Chirac's electoral promises that a proposal of law has slowly emerged, passed in January 1997. The new scheme that creates a «dependence specific benefit» (prestation spécifique dépendance- PSD) has been set up at a very least. It is conceived as «aide sociale » and assistance since the benefit is just aimed at dependent elderly people living on the bread line. This is one first fundamental differences with the field of early childhood care.

Both fields also differ by the role played by territorial public authorities. Childhood care provision remains mainly shaped and financed by national social protection bodies (the family fund of social security) with an universalistic logic (development of collective services, financial support to households utilising registered childminders, etc). Financing from other bodies are complementary (communes for day care centres, State through tax credits). On the other hand, elderly care provision is placed only under the responsibility of «départements» and communes. The contribution of the State is close to zero. For instance, the State will not contribute to the new dependence specific allowance. Only «départements » will pay for it on their «aide sociale » budget, whereas it was initially planned that the State could at least compensate the large inequalities of means between the « départements ». 
Another difference stems from the fact that collective services (establishments) have been considerably developed and supported in the field of early childhood care because such a policy has responded to the dominant consensual norm relative to child-care, whereas they have been strongly criticised in the field of the care of elderly people, either because of their costs or their quality.

A fourth difference can be noted : various statements have criticised the public answers in terms of «money » in the field of elderly people. Public authorities have pushed to encourage answers in services (vouchers) that enable clients to find services rather on the official supply market because it is a guarantee of the creation of declared jobs or to «whiten » undeclared jobs. These debates and preoccupation's have risen only very recently in the field of child-care. But the difference does remain in this field where the direct employment of domestic helpers is now encouraged through public remuneration to the parent(s) rather than to the employee.

There is also a fifth difference concerning the targeting and the redistributive impact of recent policy measures relative to social care. In both fields, generous incentives are provided for households directly employing a carer in the home. Due to the nature of such employment and because such incentives take the form of tax credits (and social contribution exemptions in the case of child-care), these measures only concern rather well-off households. For low and average income households, however, recent decisions in both fields differ deeply from a redistributive point of view. The new dependence allowance for elderly people is an assistance scheme targeted at the very poor. There is not any public measure for most other dependent elderly people who have to rely on the informal sector, i.e., their own, their spouse, their family, which means above all the female members. On the contrary, available child-care arrangements are not within low income families' pocket, the new schemes are not suited to this population and no recent measure concerning these families has been implemented to really improve this situation. Average income families, together with high income families, are increasingly encouraged to utilise registered childminder's services thanks to social contribution exemptions, income tax credits and family benefits.

Beside these differences, the movement of convergence of both fields has accelerated with the impulse of employment policy. The main trend consists of encouraging the development of direct jobs caring for children or dependent elderly people by increasing financial benefits and tax credits. This evolution of bringing both fields closer together with the development of various incentives to families recruiting paid external help for care work could reinforce the idea that France is engaged in a movement of commodification of care. One should however not neglect the important nuances distinguishing France from other European countries, notably the United Kingdom. If the movement is current, it is much more recent and more hidden. Moreover, this recent trend may take other forms than in other European countries where commodification of care often means State financial withdrawal. Decisions, especially in the case of child-care where public expenditure is higher than ever, do not aim particularly at reducing social budgets. Only the last recent measure for dependent elderly people, i.e. the "prestation spécifique dépendance", indicates an explicit reticence from the government to spend any more. This introduction of the market in caring is, currently, characterised by an important public subsidisation of 
individual care arrangements, notably through social contributions exemptions and income tax credits. The public level withdraws to a certain extent only as a caring provider, not as a global contributor. Commodification of care does not appear as a goal in itself like in some other countries, but rather as a means to create more (carer) jobs. In this framework, the State is ready to pay a certain price to enhance individual demand for carers.

The development of direct jobs has also very important «gendered» effects, especially for women whose paid work already consisted of providing care. Contrarily to the evolution that predominated before, there is less concern to improve the qualifications with training and to increase professional status levels for those who are involved in tasks of caring, and it is more a question of creating «jobs », even if these jobs are (short) part-time, precarious and without any long-term prospects. The professional carers tend to change, passing from the status of employee with effective legal guarantees in public local institutions («centres communaux d'action sociale ») to a limited duration job hired directly by the "client", which in France is a term that was previously rather reserved to the market sectors (by opposition of "usagers", users, of public services, for instance). As paid carers are quasi exclusively female, the threat is thus considerable because it participates in the current movement of reinforcing gender discrimination in the workplace in a climate of a precarious labour market. The development of unqualified carers for children as well as for dependent elderly people which should be a subject of concern, is now relatively absent in current dominant discourses. 


\section{References}

Afsa C. (1996), "L'activité féminine à l'épreuve de l'allocation parentale d'éducation", Recherches et Prévisions, ${ }^{\circ} 46$, décembre.

Attias-Donfut C. (ed) (1995), Les solidarités familiales entre générations. Vieillesse, familles Etat, Nathan, Paris.

Bachelot R., Chamart J. Y. (1993), "Proposition de loi sur la dépendance", Journal officiel, Assemblée Nationale, $\mathrm{n}^{\circ}$ 90, 20 avril.

Boissières C. (1997), Prestations familiales, Caisse nationale des allocations familiales, Paris.

Bouget D., Tartarin R (eds) (1990), Le prix de la dépendance, La Documentation Française, Paris.

Boulard, J.C. (1991, Vivre ensemble, Rapport d'information déposé par la Commission des Affaires Culturelles, familiales et sociales sur les personnes âgées dépendantes. Assemblée Nationale $\mathrm{n}^{\circ} 2135$, Juin 1991. Paris.

Bouyala N., Roussille B. (1982), L'enfant dans la vie - Une politique pour la petite enfance, rapport au secrétaire d'Etat à la Famille, La Documentation Française.

Causse L., Fournier C. et Labruyère C. (1997), Le développement des emplois familiaux. Effets sur les métiers de l'aide à domicile, CEREQ, Série Observatoire, document $\mathrm{n}^{\circ} 121$.

Colvez A. (1990), "Panorama de la dépendance en France", Revue Française des Affaires sociales, $\mathrm{n}^{\circ} 1$, janvier-mars.

CREDOC (1997), Opinions sur les prestations familiales et sur les modes de garde, enquête Conditions de vie et aspirations des Français, mars.

Desplanques G. (1993), "Garder les petits : organisation collective ou solidarité familiale", in INSEE (1993), La société française - Données sociales, Paris.

Duran P., Thoenig J-C. (1996), "L'Etat et la gestion publique territoriale", Revue française de sciences politiques, vol. $46, \mathrm{n}^{\circ} 4$, p. 580-623.

Elguiz F. (1997), La prestation spécifique dépendance, TSA Editions, Paris.

Evers A. Leichsenring K. (1994), "Paying for informal care", Ageing International, vol XXI, $\mathrm{n}^{\circ} 1,29-40$.

Evers A. Pijl M., Ungerson C. (Eds) (1994), Payments for care. A comparative overview, European Center, Vienna, Avebury.

Fagnani J. (1995), "L'allocation parentale d'éducation : effets pervers et ambiguïtés d'une prestation", Droit social n ${ }^{\circ}$, Paris.

Fagnani J. (1996), "Retravailler après une longue interruption le cas des mères ayant bénéficié de l'allocation parentale d'éducation", Revue Française des Affaires Sociales n³ - 1996.

Fagnani J. (1997a), "Recent Changes in Family Policy in France: Political Trade-offs and Economic Constraint", in Drew E, Emerek R., Mahon E. (eds), Reconciling Family and Working Live, Routledge.

Fagnani (1997b), "L'allocation de garde d'enfant à domicile : profil des bénéficiaires et effet d'aubaine", Droit Social, novembre 1997.

Fagnani J., Grignon M. (1997), "La politique familiale en France depuis les années quatrevingt : des préoccupations natalistes aux politiques de l'emploi", in Ronsin F., Le Bras H., Zucker-Rouvillois E. (eds), Démographie et Politique, Editions Universitaires de Dijon, Dijon.

Fagnani J., Rassat E. (1997a), "Les bénéficiaires de l'AGED : où résident-ils ? Quels sont leurs revenus ?", Recherches et Prévisions n 47 , mars.

Fagnani J., Rassat E. (1997b), "Garde d'enfant et/ou femme à tout faire ? Les employées des familles bénéficiaires de l'AGED", Recherches et Prévisions $\mathrm{n}^{\circ} 49$, septembre.

Fenet F, Enjolras B. (1992), "L'accueil des jeunes enfants", Informations Sociales n²3, Paris. 
Fourcade, J.P. (1993) "Proposition de loi tendant à instituer une allocation aux personnes âgées dépendantes", Journal officiel du Sénat, 5 mai 1993, Paris.

Gisserot H. (1997), Pour une politique globale de la famille, rapport du Comité de la Conférence sur la Famille, février.

Guillot O., Jankéliowitch-Laval E. et Reinstadler A. (1997b),"La garde des jeunes enfants dont la mère travaille", Recherches et Prévisions n49, septembre.

Hée Bernadette (1995), "Projections nationales d'effectifs d'élèves du premier degré pour les rentrées 1995 et 1996", Note d'information 95.07, Direction de l'évalutation et de la prospective, Ministère de l'éducation nationale.

Hinrichs K. (1996), "L'assurance soins de longue durée : une innovation institutionnelle de la politique sociale allemande", in Comparer les systèmes de protection sociale en Europe, MIRE « Rencontres et recherches », Vol. 2, Rencontre de Berlin, p. 299-330

Igl G. (1994), "La prise en charge de la dépendance des personnes âgées : les discussions et les solutions en Allemagne", in F. Kessler (Ed) (1994), La dépendance des personnes âgées : un défi pour le droit de la protection sociale, Presses universitaires de Strasbourg, p. 9-17.

INSEE (1994), Les familles monoparentales, contours et caractères, Paris.

Jobert B. (1993), "Une non-décision exemplaire : les pouvoirs publics et la politique de dépendance des personnes âgées", in O. Kuty \& M. Legrand (Eds), Politiques de santé et vieillissement, Actes de colloque AISLF, p. 41-51.

Joël M-E. (1995), "Dépendance et protection sociale en Europe", Revue française des affaires sociales, ${ }^{\circ} 4$, oct-déc., p. 161-178.

Joël M-E. (1997), La protection sociale des personnes âgées en France, Rapport pour les communautés européennes, LEGOS, Université de Paris-Dauphine.

Joël, M.E. ; Bungener, M. (1991), Le financement de la prise en charge de la dépendance des personnes âgées, Convention d'étude à la demande de Monsieur le Ministre des Affaires Sociales pour la MIRE, LEGOS, janvier. Paris.

Joël M-E., Martin C. (1994), "Payment for care : The case of France", in Evers A. Pijl M., Ungerson C. (Eds) (1994), Payments for care. A comparative overview, European Center, Vienna, Avebury, p. 165-189.

Joël M-E., Martin C. (1996), L'organisation du soutien à domicile des personnes âgées dépendantes. Déterminants économiques et familiaux, Rapport de recherche pour la MIRE et la Fondation de France, 130 pages.

Joël M-E, Martin C. (1997), "La part des arbitrages économiques et familiaux dans l'organisation du soutien à domicile des personnes âgées dépendantes", Revue française des affaires sociales, $\mathrm{n}^{\circ}$ hors série, octobre, Paris, La documentation française, p. 95-108.

Journal officiel du Sénat $\left(\mathrm{n}^{\circ} 236\right)$ "Proposition de loi relative à la prise en charge des personnes âgées dépendantes", présentée par M.M. Puech et Jourdain', n 236, 23 décembre 1992

Journal officiel du Sénat ( $\mathrm{n}^{\circ}$ 295) "Proposition de loi tendant à instituer une allocation aux personnes âgées dépendantes", présentée par M. J.P. Fourcade', n² 295, 5 mai 1993.

Kahn A., Kamerman S. (1994), Social Policy and the under-3s - Six Country Case Studies, Cross-National Studies Research Program, Columbia University School of Social Work, New-York.

Kerjosse R., Lebeaupin A. (1993), "Un million et demi de personnes âgées dépendantes" in La Société française, Données sociales 1993, INSEE, p. 536-540.

Kerschen, N (1992), "La dépendance saisie par le droit", Revue de droit sanitaire et social, $\mathrm{n}^{\circ} 3$

Kerschen N., Mercat-Bruns M. (1993), "Towards Reform of Long Term Care in France", Ageing international, vol XX, n², p. 20-26.

Kessler F. (Ed) (1994), La dépendance des personnes âgées : un défi pour le droit de la protection sociale, Presses universitaires de Strasbourg. 
Kessler F. (1995a), "Quelles prestations pour les personnes âgées dépendantes ? Panorama des propositions de réforme", Droit social, $\mathrm{n}^{\circ} 1$, p. 85-94.

Kessler F. (1995b), "Dépendance des personnes âgées : premier commentaire de «l'expérimentation »", Revue de droit sanitaire et social, n³1 (1), p. 216-224.

Kessler F. (1997), "Les normes du Conseil de l'Europe et la législation française sur la dépendance", Revue française des affaires sociales, $\mathrm{n}^{\circ}$ hors série, octobre, Paris, La documentation française, p. 215-228.

Laroque P. (1962), Politique de la vieillesse, Rapport de la commission d'étude des problèmes de la vieillesse.

Laroque, G. et al. (1993), Rapport sur la dépendance des personnes âgées, Inspection générale des Affaires sociales, janvier. Paris.

Lesemann F., Martin C. (Eds) (1993), Les personnes âgées. Dépendance, soins et solidarités familiales. Comparaisons internationales, Paris, La documentation française.

Lewis J., Glendinning H. (1996), Implementing the New community Care, Open University Press.

Long Martine (1997), "La prestation d'autonomie : une nécessité reportée", Revue française des affaires sociales, $\mathrm{n}^{\circ}$ hors série, octobre, Paris, La documentation française, p. 247 262.

Martin C., Jourdain A., Mohaer F., Schweyer F-X (1996), La prestation expérimentale dépendance en Ille et Vilaine. Leçons d'un apprentissage, LAPSS/ENSP, éditions ENSP, 177 pages

Martin C. (1998), "L'expérimentation territoriale de la prestation dépendance : fenêtre d'opportunité ou rendez-vous manqué ?", Politique et management public $\mathrm{n}^{\circ} 1$ (in press).

Math A., Renaudat E. (1997), "Développer l'accueil des enfants ou créer de l'emploi ? Une lecture de l'évolution des politiques en matière de modes de garde", Recherches et Prévisions $\mathrm{n}^{\circ} 49$, septembre.

Norvez A. (1990), De la naissance à l'école. Santé, modes de garde et préscolarité dans la France contemporaine, PUF-INED, Cahier $n^{\circ} 126$, Paris.

Renaudat E. (1993), "Les salariés en congé parental", Recherches et Prévisions n³2, Paris.

Sauviat C. (1996), "Coûts de maind-d'oeuvre, emploi et qualité dans des marchés de service : la garde d'enfants et le nettoyage industriel", La Revue de l'IRES, n²2, Automne 1996.

Schopflin, P. (1991), Dépendance et solidarité. Mieux aider les personnes âgées, Rapport de la Commission du Commissariat Général du Plan, La Documentation Française, Paris.

Van de Walle I. (1997), "Le congé parental : stratégies d'employeurs et de salariées", Recherches et Prévisions, $\mathrm{n}^{\circ} 49$, septembre.

Yakubovich Y, Grignon M. (1996), "Cas-types sur les modes de garde des jeunes enfants quand la mère de famille travaille à plein temps", note du bureau des prévisions, Caisse nationale des allocations familiales, Paris. 